\title{
Corruption and Life Satisfaction in Transition: Is Corruption a Social Norm in Eastern Europe?
}

\author{
Chiara Amini ${ }^{1} \cdot$ Elodie Douarin ${ }^{1}$
}

Accepted: 16 May 2020 / Published online: 2 June 2020

(c) The Author(s) 2020

\begin{abstract}
To explain a so-called "happiness gap" between citizens of Eastern Europe and comparable individuals from other regions, researchers have pointed at low governance quality, and corruption in particular, as a possible cause. However, this explanation seems incompatible with the "broken windows" paradigm, which posit that in high-corruption environment, victims of corruption tend to report a lower psychological cost of victimisation. Our paper contributes to the literature by explicitly tackling this potential contradiction. Our results nuance our understanding of the role of corruption on people's life satisfaction in Eastern Europe by investigating the extent to which the subjective cost of corruption depends on its pervasiveness. We demonstrate: (1) large individual cost associated with different measures of corruption, (2) a small reduction in these costs for some measures of corruption as it becomes more pervasive and (3) large inequalities in the cost of corruption depending on education and income. Overall, we conclude that, for the population as a whole, there is limited evidence of corruption being a social norm in Eastern Europe, in the sense that pervasiveness does not reduce individual cost.
\end{abstract}

Keywords Happiness $\cdot$ Subjective well-being $\cdot$ Corruption $\cdot$ Easter Europe $\cdot$ Social norms

\section{Introduction}

Is paying a bribe less painful in context where this behaviour is pervasive? Are people less affected by their own experience with corrupt officials if they think it is just what most people also experience? This is what we propose to investigate here, by measuring the life satisfaction cost of corruption, in the context of Central and Eastern Europe and Central Asia, a region known for its high prevalence of corruption. ${ }^{1}$

1 For example, according to transparency international (transparency.org accessed on 07/04/2020) Eastern Europe and Central Asia, as a region, records the second lowest score on its "Corruption Perception Index" in 2019 (the index scores countries on a scale of $0-100$, with 0 for highly corrupt and 100 for very clean

Chiara Amini

Chiara.amini@ucl.ac.uk

Elodie Douarin

e.douarin@ucl.ac.uk

1 School of Slavonic and East European Studies (SSEES), University College London (UCL), Gower Street, London WC1E 6BT, UK 
Life satisfaction ${ }^{2}$ is increasingly used to understand how people value different aspects of their lives and the trade-offs that they may face. Both in aggregate and individual-level studies, there are today a number of well-established stylized facts relating to what can generally be seen as a "good life". At the same time, there has also been a growing interest in understanding how context impacts on individual life satisfaction, i.e. the extent to which one considers a "good life" may differ depending on where they live and what others around them value. In this spirit, researchers have tried to explain regional or country level differences in the appreciation of life using contextual controls to account for the effects of aggregate variables, including social norms or culture. ${ }^{3}$

One of the interesting puzzles investigated within this literature is the so-called "Eastern European Happiness Gap". As discussed for example in Easterlin (2009) and dissected by Guriev and Zhuravskaya (2009), people in the former soviet bloc appeared less satisfied with their life than comparable individuals, with similar socio-economic conditions, in neighbouring countries. In particular, it was shown that life satisfaction had plummeted in the region in the early 1990s, and recovered slowly afterwards, thus following the GDP "J-curve" associated with the implementation of market reforms (e.g. Helliwell 2003 or Sanfey and Teksoz 2007). However, life satisfaction did not recover as rapidly as GDP and on average Central and East Europeans remained less satisfied with their life than their western neighbours, at least until 2016, when the gap reportedly closed (Guriev and Melnikov 2017). In Guriev and Zhuravskaya's work, a number of explanations were put forward to explain this gap, including skills' obsolescence, dissatisfaction with rising level of inequality and lower quality of public goods, as well as increased level of uncertainty and macroeconomic instability since the beginning of the transition away from central planning. As this happiness gap persisted, other explanations were put forward, and most of the recent investigations has emphasised the role of low institutional quality (e.g. RodríguezPose and Maslauskaite 2012 or Nikolova and Sanfey 2016), and in particular corruption (Djankov et al. 2016). However, this particular explanation overlooks the direct impact on individual's wellbeing of experiencing corruption, by focusing only on the aggregate effect of average country-level corruption. Thus, although the so-called Eastern European

Footnote 1 (continued)

countries), second only to Sub-Saharan Africa. Only three countries in the region record a score above the global average of 43, namely Georgia at 58, Montenegro at 45 and Belarus at 44. The EU-members of Central and Eastern Europe in the meantime, do slightly better overall, but with large variations in their performances. For example, while Estonia scores an impressive 74, and Lithuania scores much lower, but still at a respectable 60. Poland (58) and Czech republic (56) still lag behind most of Western Europe (with the exception of Italy at 53), while Romania and Hungary (both at 44) or Bulgaria (43) are at, of very close to, the global average only.

${ }^{2}$ We need to clarify here our choice of vocabulary. Our analyses in this paper are about life satisfaction only, but we will use the terms "life satisfaction", "subjective well-being" and "happiness" interchangeably. Subjective well-being is a broader concept encompassing cognitive and emotional evaluation of life, and thus it includes both life satisfaction (a more evaluative measure of well-being) and happiness [which is more about emotional well-being), as detailed in Diener et al. (2003) for example. We also note that determinants of life satisfaction and happiness have been shown to differ (see for example Kahneman and Deaton (2010) on the role of income], the distinction is thus not trivial. However, in keeping with the literature we cite, we will use those terms ("life satisfaction", "subjective well-being" and "happiness") interchangeably. Doing so is common practice in particular among economists (as the "economics of happiness" generally refers to investigations into the economics of life satisfaction, and the "East European happiness gap", a strand of literature we will review in this paper, is really a life satisfaction gap).

3 see for example Senik (2014) on why French people may be intrinsically miserable, or the literature on migration and life satisfaction (e.g. Nikolova and Graham 2014). 
Happiness Gap has closed, a number of questions remain unanswered regarding the factors that actually explained it.

We thus offer to bridge this gap by investigating the links between corruption-measured through individual experience of bribe paying and importance of political connections, and aggregate pervasiveness - and life satisfaction in Eastern Europe using the second Life in Transition Survey: a household survey collected across the transition region (defined as the countries of Eastern Europe which started transforming away from central planning from 1989 onward) plus a few comparator countries, in 2010 (before the closing of the gap) by the European Bank for Reconstruction and Development and the World Bank. ${ }^{4}$ More specifically, our contribution to the literature is twofold. First, we explore whether in countries with a high incidence of corruption, individuals engaging in corrupt activities find it less psychologically costly than in lower incidence context. We measure this psychological cost as the individual loss of life satisfaction associated with reported corruption, either experienced or perceived (measured through bribe paying "by me", "by others like me" or the perceived importance of political connection). In other words, this psychological cost is captured by the (negative) coefficient estimated for the variables measuring corruption in a life satisfaction regression. This means that in this paper, "psychological cost", "subjective wellbeing cost", "individual cost" and "cost of victimisation" are synonymous. Essentially, we are asking whether as the incidence of corruption increases, paying bribes becomes a social norm that people simply internalise and adhere to (Coleman 1990, pp. 243-244), and thus people suffer less from engaging with it (Graham and Chattopadhyay 2009). Hence, our definition of social norm is based on observed behaviour or perception (descriptive norm or behavioural norm) acting as guidelines for what is acceptable or not in a given society or social context (Cialdini and Trost 1998). High incidence of a specific behaviour usually seen as undesirable for moral, ethical or identity reasons (a norm based on what ought to be, which we will refer to as moral norm for simplicity) can reduce the otherwise negative cost associated with this behaviour, as the observable/behavioural social norm dampens the moral one. ${ }^{5}$ Following a useful review of the underlying concepts presented in Cialdini and Trost (1998), we are thus recognising that the subjective acceptance of a given practice (corruption) depends on each individual's subjective views (their personal moral values), and the specific norms of the social group or society in which this individual lives. This "social norm" element is reflected in how frequently the practice is performed and provide a guideline for effective action ("this is how things are done around here") and information regarding the behaviours that others in a specific social group might expect: it is thus also an injunctive norms guiding behaviour with the goal of building and maintaining social relations within this group. In practice, we thus investigate if there is some adherence to this behavioural norm, which would imply that the impact of corruption on individual subjective well-being is lower in context where corruption is more prevalent. In Cialdini and Trost's words (1998, p. 162), "descriptive-norm information can work to make salient the appropriate injunctive norms" and thus the prevalence of a given behaviour in society might make it more acceptable even for people who hold opposite personal norms. ${ }^{6}$ Second we investigate possible differences across social groups, scrutinising the

\footnotetext{
${ }^{4}$ For a full list of countries, see Table 6 in "Appendix".

5 As pointed out by a reviewer: this is also compatible with the broader literature on social comparison, which we will discuss in Sect. 2.4.2.

6 We conceptualise social norm here, as something which through increased incidence (observed or perceived average behaviour in the relevant population) becomes less psychology costly. Such a definition has been used by economists studying the impact of unemployment on well-being (see Clark 2003 on unem-
} 
relationship between life satisfaction and corruption depending on the education level of the respondents and their socio-economic background.

In doing so, we thus contribute to the recent literature investigating the determinants and consequences of corruption at the individual level, focusing on the role of individual characteristics and social or cultural norms (e.g. Graham and Chattopadhyay 2009; Graham 2011 or Rotondi and Stanca 2015).

Overall this paper, while confirming broad stylised facts on corruption and well-being, adds to the existing literature by presenting evidence on the complex relationship between corruption and life satisfaction in Central and Eastern Europe. First, in agreement with the previous literature, we find that country-level variables measuring control-of-corruption (World Governance indicator, based on expert views and perception of corruption at the country level) explain most of the gap in life satisfaction between East European and comparator countries. In addition, we identify large costs associated with the individual experience of corruption, as well as aggregate corruption. Second, we report evidence that the cost of individual-level corruption is decreasing across the region when aggregate corruption is higher, however this effect is very small in magnitude, and not found consistently over all indicators of corruption. Overall our findings are thus presenting very limited support for the notion that corruption is a social norm in Central and Eastern Europe, as those who are demanded to pay bribes (or think they are at higher risk of being asked or rely on political connections) do not find it less painful when the incidence of bribe-paying (or reliance on political connections) is larger. Finally, we document systematic differences in the cost of corruption according to the income and education level of respondents.

\section{Literature Review}

\subsection{Happiness and Reforms}

The political and economic changes experienced across Central and Eastern Europe following the fall of the Berlin Wall have been both far-reaching and rapid. The countries of the region generally experienced fast economic reforms, around the three pillars of liberalisation, privatisation and macroeconomic stabilisation, but these reforms also meant a complete institutional overhaul (Douarin and Mickiewicz 2017). In that context, short-term costs were likely to occur, both as individuals adapted to a new and initially chaotic environment, and through the trial and errors inherent to such a broad programme of transformation. Importantly, the literature focusing on the post-communist transformation has commented on the impressive economic catch-up that have been observed for at least part of the region, but institutional quality is still lagging behind (e.g. Roland 2014). Interestingly, life satisfaction studies can shed some light into the well-being trade-offs that exist for the affected population. Indeed, life satisfaction seems like an ideal indicator to capture the combined well-being effects of these changes, accounting both for the direct economic

Footnote 6 (continued)

ployment) or social scientists studying the impact of corruption on life satisfaction (see for example Graham 2009, 2011) but never in the context of Eastern Europe. This literature is reviewed in Sect. 2.4. We note in particular that in this definition, respondents would still recognise corruption as morally wrong or undesirable, but would find it less damaging to engage in corruption, if "everyone else does". 
impact of reforms on individuals or households, but also for effects through changing context and expectations.

For this reason, a number of papers have indeed investigated the drivers of life satisfaction, beyond Central and Eastern Europe, over periods of intense change. For example, Lora and Chaparro (2008) investigating life satisfaction in countries undergoing reforms in line with the Washington Consensus, concluded that even though these reforms were generally associated with growth, and sometimes rapid and prolonged growth, they were also often associated with a decrease, rather than an increase, in life satisfaction. They argue that this is likely to be due to rising expectations and aspirations, which then lead to a degree of disappointment, even as reforms raise living standards.

This means that even though generally the empirical literature identifies a positive relationship between absolute income and life satisfaction, and relative income seems to play only a small role (Stevenson and Wolfers 2008), in the specific context of intense reforms, the importance of rising inequality and the need to manage the expectations of the population when implementing broad economic reforms is now well documented. Indeed, in both China (Easterlin et al. 2012) and Eastern Europe (Sanfey and Teksoz 2007), an inverted U-shaped evolution of life satisfaction has been documented over several decades of transformation-whereby in the initial years of reforms life satisfaction decreases, before rising again. In Eastern Europe, this inverted U-shaped followed roughly the pattern of GDP growth, reaching a low in the mid-1990s, after which both life satisfaction and GDP rose again on average for the region, but life satisfaction much more slowly than GDP (Sanfey and Teksoz 2007). In China, happiness decreased even as GDP was rising in the early stages of reforms, before rising again, even though overall life satisfaction appears to have not changed or even decreased after 30 years of growth (Easterlin et al. 2012; Morgan and Wang forthcoming). Instead rising unemployment, rising inequality and the weakening of safety nets appear to explain most of the life satisfaction trajectory (Morgan and Wang forthcoming).

Overall, the literature clearly points towards a loss of life satisfaction associated with increased uncertainty and rising unemployment-some of the likely short-run impacts of economic reforms. However, once the economy has stabilised and recovered, happiness tends to rise again (Selezneva 2011).

\subsection{The East European Happiness Gap}

In Central and Eastern Europe however, the transformation away from central planning towards market economies was characterised with a persistent happiness gap, which persisted beyond the return to stability and economic growth. Indeed, most studies on individual countries report a decline in life satisfaction since the beginning of the post-communist transformation in the region (e.g. Saris 2001; Veenhoven 2001). This is not surprising given the amount of disruption witnessed in the early 1990s when GDP collapsed, unemployment shot up and social safety nets were disrupted. In the longer-run, a number of papers including two large cross-countries studies (Guriev and Zhuravskaya 2009; Easterlin 2009) reported a U-shaped trend in life satisfaction, with subjective well-being plummeting in the early 1990s but increasing later on, broadly following the economic recovery of GDP. However, the increase in life satisfaction in the region fell short of the increase in income, as the average level of happiness reported by individuals across the region was lower than the happiness reported by people living in comparable conditions in neighbouring countries. More specifically, Guriev and Zhuravskaya (2009) explored the trends and 
determinants of subjective well-being in the 1990s in six Eastern European countries (i.e., Bulgaria, Croatia, Czech republics, Kyrgyzstan, Poland and Romania) and they concluded that the population had experienced no significant increase in life satisfaction in spite of their economic recovery. Their empirical analysis shows that individuals in post-communist countries are significantly less happy compared to those residing in other regions, even after controlling for numerous individual level characteristics. Guriev and Zhuravskaya (2009) then broadly identified four causes behind this gap:

- First, human capital obsolescence, which has already been discussed above,

- Second, the experience of extreme level of (macroeconomic) instability, generating a greater sense of uncertainty and anxiety.

- Third a deterioration in the quality of public good provided and

- Fourth rising inequality.

However, these four factors could be expected to weaken in the longer run, after the initial turbulences of the post-communist transformation, allowing these new market economies to close their happiness gap. Recent investigations into the unhappiness of East European have thus focused on another explanatory factor: institutional quality. Even if this happiness gap has reportedly closed in 2015-2016, unanswered questions remain, and our analysis thus aims at bringing new light into the likely role of low institutional quality and corruption in explaining the happiness gap using data from 2010-i.e. before the gap closed.

\subsection{Institutional Quality and Corruption}

Contributions by Frey and Stutzer (2000) and Di Tella et al. (2003) have been particularly instrumental in popularizing a joint investigation of micro and macro determinants of life satisfaction. In particular, Frey and Stutzer discuss three levels of controls that can be relevant to life satisfaction: namely individual level variables, macroeconomic and institutional variables. With this in mind, a recent but growing literature focuses on the relationship between life satisfaction and the political and institutional environment. Research shows for example that high levels of democracy and democratic participation are positively and significantly associated with subjective well-being (Frey and Stutzer 2000; Helliwell and Huang 2008). Helliwell (2003) finds that there is a significant association between life satisfaction and the World Bank Governance indicators globally.

In Eastern Europe as well, these institutional quality variables have been shown to matter, and the most recent literature documenting the Eastern European happiness gap has mostly focused on institutional quality as a key explanatory factor. Djankov et al. (2016) indeed conclude that lower institutional quality, and corruption in particular, is likely to explain a large share of the Eastern European happiness gap. Using cross-countries regressions and a cross section of individual-level observations, their results highlight that higher level of corruption and poorer governance in Eastern Europe contribute to significantly lower level of well-being. Rodríguez-Pose and Maslauskaite (2012) also focus on corruption to explain a slower-than-expected rise in life satisfaction across the region when economic growth resumed. Their analysis is based on the European Value Survey and investigates the relationship between subjective well-being and corruption, government spending and decentralization across time, to conclude that low institutional quality explains a persisting happiness gap. Finally, Nikolova and Sanfey (2016), using data from the World 
Value Survey, shows that political institutional quality, captured through the rule of law, explains part of the happiness gap in Eastern Europe.

\subsection{The Link Between Corruption and Subjective Well-Being and the Interplay Between Context and Individual-Level Experience}

\subsubsection{Aggregate Corruption Versus Individual Experience of Corruption}

Recent research has analysed the role of aggregate corruption in explaining unhappiness in Eastern Europe (notably Rodríguez-Pose and Maslauskaite 2012; Djankov et al. 2016). Aggregate corruption in the region is seen as negatively impacting subjective wellbeing, both in regressions focusing on average levels of life satisfaction (Djankov et al. 2016) and in regressions trying to explain individual levels of life satisfaction (Rodríguez-Pose and Maslauskaite 2012). However, this literature on the aggregate cost of corruption ignores the individual cost of victimisation, when the negative effect of individual experience with corruption on life satisfaction has been discussed extensively in the broader literature.

Indeed, corruption may have a direct as well as indirect effect on well-being. If it seems obvious that paying bribes will have a direct economic and psychological costs for the victims, the research on corruption has sometimes found that bribery could in fact allow individuals to by-pass stifled bureaucratic procedures and thus generate individual gains, resulting in an ambiguous impact (Graham 2011). Empirical evidence however tend to support the notion that corruption victimization has a negative impact on individuals (as evidence in a number of studies including Graham 2011; Sulemana et al. 2017 or Wu and Zhu 2016). In addition to one's perception or experience of corruption, contextual or macrolevel corruption is generally expected to be unambiguously detrimental to subjective wellbeing, and the bulk of the empirical literature linking it to life satisfaction has focused on this macro-level relationship (Helliwell and Huang 2008). But interaction effects between individual and aggregate costs of corruption complicate the picture. Indeed, where corruption is pervasive, individuals may experience a feeling of violation and injustice, independently of actual victimization, which also decreases subjective well-being (Tay et al. 2014). At the same time, it is likely that there will be less stigma associated with victimisation in context of pervasive corruption, and thus the cost of victimisation might be lower in high-corruption context. However, such a moderating effect of aggregate corruption seems counter-intuitive if high aggregate corruption is indeed a credible factor explaining the East European happiness gap. It is thus interesting to note that to date such a moderating effect has been evidenced in different contexts, but it has not yet been investigated in Eastern Europe.

It thus seems important to complement the evidence currently available in the literature with a detailed analysis taking into account both the cost associated with individual-level measures of corruption and the cost associated with aggregate corruption, plus their potential interaction.

\subsubsection{Interaction Terms: Social Norms, Social Comparisons and "Broken Windows"}

Interaction terms between an individual-level variable and its aggregate, context-level counter-part is often investigated in the literature in settings where the response to an individual-level negative experience is expected to depend on how pervasive this experience is. Thus, the mitigating effect analysed is often interpreted as reflecting "social norms", in 
the sense of behaviour commonly observed, and thus accepted, in a given society (Cialdini and Trost 1998). Indeed, both the economics as well as the psychological literature have explored how behaviours widespread in society ${ }^{7}$ may play a role in relation to individual well-being (Clark 2003; Graham 2009, 2011).

This mitigating effect is sometimes associated with Festinger's (1954) theorisation of the role of social comparison. In his work, the drive and necessity for self-evaluation lead people to compare themselves to others. As a result, the behaviour of others in turn shapes individual behaviours and opinions. A well-established area where such a mitigating effect has been investigated is unemployment. For instance, Clark (2003) finds evidence that the well-being of an unemployed individual is strongly correlated with the unemployment level in a relevant peer group, with the unemployed reporting relatively lower reduction in wellbeing associated with losing their job, when the local level of unemployment is high (see also Clark and Oswald 1994 or Anderson 2009 for concurring findings and discussions). In other words, when unemployment is common enough to be perceived as relatively normal, as something which is "within the norm" in a given social context, experiencing unemployment has been shown to be less costly to the wellbeing of a given individual. ${ }^{8}$ Such a reduction in the negative cost of a specific experience, when it is shared with peers, has also been investigated in relation to crime victimisation (Graham and Chattopadhyay 2009; Powdthavee 2005) or for cancer patients (Taylor and Lobel 1989).

In line with this research but focusing on bribe paying specifically, Graham and Chattopadhyay (2009) and Graham (2011) posit that corruption should have a stronger negative effects on life satisfaction in context where its incidence is actually low. In other words, the individual costs of paying a bribe can be mitigated through observed behaviour in a given society or behavioural social norms. In the corruption literature, this expectation that aggregate levels of corruption might mitigate the cost of one's experience of corruption is sometimes linked to the "broken windows" theory, which states that broken windows in a specific neighbourhood might be interpreted as a sign that nobody cares and might thus make it easier for people to engage in behaviours that would otherwise be described as anti-social and morally wrong (Kelling and Wilson 1982). In other words, broken windows are interpreted as reflecting of social norm of relative tolerance towards anti-social behaviour, which then makes it easier for individuals to engage in this behaviour-they are only adhering to social norms. Beyond this intuitive argument, quantitative evidence suggest that such a mitigating effect through behavioural social norms does exist in Latin America, both in the context of crime and corruption victimisation (Graham and Chattopadhyay 2009; Graham 2011), and in Mainland China for corruption victimisation (Wu and Zhu 2016). In both China and Latin America, it has thus been demonstrated that engaging in corruption is less psychologically painful when the aggregate level of corruption (at the regional and country-level respectively) is higher.

Two potential underlying mechanisms can explain this mitigating effect according to $\mathrm{Wu}$ and $\mathrm{Zhu}$ (2016), as observed norms, social comparison and broken windows can all serve to reduce guilt of taking part in a morally wrong activity or reducing the stigma of

\footnotetext{
7 In our case we will define social norms as observed or perceived behaviour prevailing in a country. This is distinct from a moral norm, which would refer to what people ought to do. We note that if a behaviour is more accepted because it is pervasive, it does not imply that people do not see it as wrong.

${ }^{8}$ On the other hand, in context where there is a strong cultural norm to work (a social norm based on identity or values, rather than observed incidence of work), the psychological cost of unemployment will be higher (Roex and Rozer 2018).
} 
victimisation. Both these mechanisms reflect the nature of social norms. Indeed, not following social norms can be associated with social sanctions (for example a loss of reputation), or can relate to self-inflicted sanction (when social norms have been internalised). Reduced stigmatisation can thus be interpreted in terms of avoided social sanction, while reduced guilt can be associated with reflecting an internalised norm.

If such a mitigating effect exists in Eastern Europe, adjustment to the observed social norms of corruption would reduce the negative effect of individual corruption on wellbeing in high corruption context.. Investigating these complex effects is thus important for our understanding of the impact of corruption in Eastern Europe, and in particular, it can help us nuance its role in explaining the relatively low level of life satisfaction observed across Eastern Europe until 2015-2016.

\section{Hypotheses}

On the basis of what we have just discussed, we can formulate a number of testable hypotheses. First, we will posit that both individual and aggregate corruption levels have a negative impact on life satisfaction, as suggested elsewhere in the literature:

H1a Increased individual experience or perception of corruption has a negative effect on life satisfaction.

H1b Greater aggregate-levels of corruption also have a negative effect on life satisfaction.

Regarding the interaction between individual and aggregate-level of corruption, we will assume a mitigating effect of social norms, whereby the individual cost of corruption is lower when aggregate corruption is large:

H2 The negative wellbeing effect associated with individual experience or perception of corruption reduces in context where the incidence of corruption (aggregated corruption) is higher.

Corruption can be measured in many ways, and in our analyses, we decided to use three different indicators that are commonly found in the empirical literature. At the individual level, the incidence of corruption can be measured through bribes paying, with respondents either reporting their own experience of bribes paying (that's our first measure, which we also call "experienced corruption"), or the experience of people around them or "like them" (second measure, which we also refer to as "perceived corruption"). Views differ on which one of these two measures is likely to be the most accurate. On the one hand, some argue that respondents might be uncomfortable reporting their own illegal activities, and might be reporting more reliable figures when talking about others (for example, Wu and Zhu 2016 or Djankov et al. 2016 thus rely on "perceived" bribes paying only). On the other hand, reporting on the bribe paying of others might be purely speculative and a number of corruption experts thus prefer using own bribe paying experience (see Seligson 2006; Heywood and Rose 2014). A third measure commonly found in the literature is an individual's view regarding whether connections and favours are more important for success than efforts, hard work or skills in the country where they live. This is also a measure of perceived corruption, but not only limited to bribe paying. The main advantage of this 
measure is that it captures a broader range of informal practices, and is better suited to emerging economies where these are potentially pervasive (see for example Williams and Onoshchenko 2015). By reporting results with these three measures of corruption we will provide a detailed picture of the individual wellbeing costs of corruption in the region.

Going further, we will also explore whether this mitigating effect could differ in different groups in the population. In particular, one may want to look into the relationship between income or education and life satisfaction and how this relationship is affected by corruption. Indeed, part of the happiness gap could relate to a dissatisfaction with returns to education in corrupted economies. Early investigations of life satisfaction in the region have often discussed the fact that education less reliably predicted satisfaction with life than in other part of the world (e.g. Sanfey and Namazie 2001; Sanfey and Teksoz 2007). In particular, early papers on the happiness gap demonstrated that at least part of the gap could be attributed to skills obsolescence, for those educated in communist times (Guriev and Zhuravskaya 2009). However, re-training and changes to education systems should have progressively corrected the mismatch of education and skills that had been created by rapid restructuring. In Djankov et al. (2016) however, only tertiary education is associated with greater life satisfaction in their analysis of LiTS data from 2010 and examining jointly new EU members and countries of the Former Soviet Union.

One would further expect that in a context where connections and favours matter more than skills and competences, education can be associated with greater levels of frustration. Building on a similar intuition, Campante and Chor (2012) argue that education will be less economically productive depending on the political context, as non-economically productive activities compete to attract educated individuals' time. In our context, we can posit that a small portion of the educated elite benefit from corruption as they access positions through favours, while the majority of the population is only negatively affected. Thus, corruption increases the variation in returns to education as education increases, and may increase the returns for the most educated individuals while at the same time reducing them for most.

Focusing on income, some aggregate studies show the effect of corruption on wellbeing as being moderated by other country-level characteristics, such as the level of income. For example, using cross-country data, Arvin and Lew (2014) show that income moderates the corruption-life satisfaction relationship as corruption negatively affects wellbeing but only in high-income countries. Consistently, Welsch (2008) uses a cross section of countries to show that corruption significantly affects the aggregate-level of subjective well-being both directly as well as indirectly through GDP. At the individual level, Graham (2011) expands her discussion of a likely adaptation to corruption, by exploring factors that could potentially mitigate the relationship between subjective well-being and corruption. In doing so, she discusses income as a potential mediation channel, by drawing a parallel between corruption and crime victimization. Indeed, in the context of crime victimization, Di Tella et al. (2010) illustrated how richer individuals were more likely to find ways to protect themselves from harm, ex-ante and ex-post. What we discussed above, is consistent with the notion that at least sometimes paying a bribe can be seen positively if it allows by-passing cumbersome administrative barriers. However this is more likely to be the case for wealthier individuals, who may be better able to buy and return favours, and are less affected when parting from their cash. In this context, income may be a mitigating factor behind the effect of corruption on subjective well-being, with richer individuals being less affected by corruption victimization in context of high corruption.

The analysis of the interrelation between corruption, income and education leads to the formulation of a second set of hypotheses: 
H3a (and b) The effect of corruption on life satisfaction is mitigated by individual income (and education) level, whereby richer (and more educated) individuals are less negatively affected by greater aggregate experience or perception of corruption.

\section{Data and Methodological Approach}

\subsection{Data}

Our analysis is based on secondary data, more specifically we use the second wave of the EBRD/World Bank Life in Transition Survey (LiTS II), which was collected in 2010. It is a nationally representative household survey, covering 29 transition countries of Central and Eastern Europe, but also Turkey and five western European countries (France, Germany, Italy, Sweden and the United Kingdom), which constitute a comparator group. ${ }^{9}$ The data was collected through face-to-face interviews of individuals aged 18 or above and living in households randomly drawn (using weight proportionate to the relative size of the sampling unit) selected using census enumeration areas, stratified by region and level of urbanisation. We use the second wave of the LITS survey, which combined modules related to economic and demographic characteristics, attitudes and values, labour, education and entrepreneurship, climate change, and the impact of the global financial crisis. Importantly the survey includes a detailed module on corruption experience and perception, and was collected before the happiness gap in Eastern Europe reportedly closed (EBRD 2017).

All the variables employed in our econometric exercise are from LITS with the exception of two institutional measures that are taken from the World Bank Governance dataset.

\subsection{Variables}

Key variables of interest include a measure of life satisfaction, our main outcome variable. Two indicators of life satisfaction are available from the LITS dataset, one where individual were asked to report their satisfaction with life overall on a 1-10 Likert-scale, and a second one where satisfaction with life was measured on a 1-5 Likert-scale. In both cases, a higher score indicates a greater level of satisfaction with life. In keeping with previous work (Djankov et al. 2016; Nikolova and Sanfey 2016), we use the 1-5 Likert-scale for our main analyses, while the second measure is used for robustness checks.

Then, experience of corruption is measured in three ways (as explained in Sect. 3). First at the individual-level, we use self-reported experienced corruption as a reported experience of paying a bribe to access public services. It thus captures corruption victimisation. Then we use two measures of perception of corruption captured through two further variables constructed from the survey: (1) political connection is a dummy variable taking value one if political connection is considered more important than merit for success by the respondent and (2) perceived corruption which captures the likelihood that bribery is paid by "someone like me" when trying the access a public service, as reported by

\footnotetext{
9 This survey was previously analysed in the literature focusing on the East European happiness gap, most notably by Djankov et al. (2016): by analysing the same data and choosing a specification in line with theirs, we are making our findings directly comparable. We are also making use of the last wave of the LITS collected before the happiness gap actually closed, i.e. before 2015-2016 (Guriev and Melnikov 2017).
} 
the respondent. As previously mentioned, we rely on three different measures of corruption to account for the fact that corruption is illegal and multifaceted, making it difficult to measure. The other variables used in our analyses are standard controls in analyses of corruption.

Second at the aggregate (country) level, we employ first the national average of the individual-level corruption variables extracted from LITS, as well as two indexes from the World Bank Governance Indicators (WGI) dataset: the aggregate index which includes 6 dimensions of institutional quality (including political voice, control of corruption and rule of law) and its control of corruption dimension only. ${ }^{10}$

Table 5 presents the descriptive statistics for the entire sample, as well as for the East European countries and the rest of the sample separately. The data shows some clear differences between the groups analysed. For what concerns our outcome variable, the mean of the life satisfaction indicator, as measured on a 1-5 scale, is 3.62 for non-Eastern European countries of the sample, while it is only 3.09 for the Eastern counterpart, confirming the existence of an unconditional happiness gap. This difference is roughly equal to half of the variable's standard deviation in the full sample.

As perhaps expected, individual as well as aggregate measures of corruption are higher in Eastern Europe. For example, control of corruption, as measured by the World Bank governance indicator, is 1.19 for non-Eastern European countries in the sample (standard deviation 0.84), but it is only -0.36 for Eastern European countries (standard deviation 0.59). Both perceived and experienced corruption are higher on average in Eastern Europe, compared to the rest of the sample, but the standard errors are also much larger in the region. Other individual characteristics also show some notable differences. For instance Eastern European countries have a greater proportion of non-religious individuals and of those on low-income. Education still shows the socialist legacy, with Eastern European countries having only $29 \%$ of low educated individuals compared to $39 \%$ in the comparator group. To give a more detailed account of corruption level by country we also reported in Table 6 the country level average of all corruption measures employed in the analysis.

\subsection{Multi-level Models}

Our research focus requires the use of an econometric model that can first handle multilevel variables and second that allows us to straightforwardly test the relative gains from small changes in specification. We thus employ multilevel models, as they are meant to deal with multilevel datasets and because LR-test allows us to directly compare the variance explained by different nested models. The linear regression estimations presented in the empirical sections are all based on maximum restricted likelihood. The models presented here are random intercepts models, thus allowing us to account for systematic differences in the way respondents assess their life satisfaction in each of the countries investigated (i.e. the intercept is country-specific), and to model the existence of an average social norm effect of corruption in Eastern Europe. Random slopes models were also estimated as robustness checks and are presented in Sect. 5.2.

Ultimately here, we will estimate a model with individual level variables (including education, income and a set of standard controls), including contextual country-level indicators of corruption, as well as cross-level interactions between country-level and individual-level

10 All World Bank Governance Indicators are based on expert views and surveys on perceptions. 
corruption so that we can test whether corruption is a social norm, i.e. if its negative effect on life satisfaction reduces as it is more pervasive.

Because we are interested in the impact of (1) individual-level and (2) country-level variables, as well as (3) their interactions, a multilevel setting is highly desirable and will increase the reliability of the coefficient estimated at the aggregate level as well as for the cross-level interactions (Rabe-Hesketh and Skrondal 2012). Typically, if the hierarchical nature of the data is not accounted for, standard errors for higher level variables might be underestimated, hence the significance of the coefficients estimated for these variables would be overestimated.

The estimated specification has some obvious shortcomings. The most common critique would be potential endogeneity due to unobserved individual characteristics, in which case our estimates would produce a spurious correlation between life satisfaction and corruption. We partly address such an issue by controlling for socio-economic background as well as other variables, such as gender and father's education, that are unlikely to change over time and hence can serve as proxy for unobserved individual characteristics (Ammermueller 2007). We want to stress however that the central contribution of our analyses reside in the comparison, and the effects estimated are best understood as cross-country differences. Another issue which, has been discussed in the happiness literature is the need to model in the estimation the ordinal nature of the dependent variable. All surveys questions on life satisfaction ask individuals to categorically evaluate their quality of life (i.e. respondents are ask to rank their life satisfaction on a scale of 1-5 or 1-10). Pasta (2009) argues that ordinal variables can be modelled with linear estimator with no significant loss of information. Moreover it is very rare that a significant predictor for a categorical variable would not matter if that variable was measured on a continuous scale. Ferrer-I-Carbonell and Frijters (2004) compare estimates using OLS and using ordered probit and show that assuming interpersonal ordinality of the satisfaction answers makes little difference to the results. What is most important is controlling for time-invariant individual factors that are notably important in explaining subjective well-being.

\section{Results}

\subsection{Basic Model: Individual-Level Controls and Country-Level Random Intercepts}

Multilevel models are adopted in situation where the data analysed has been collected at different level of aggregation. In our case, we are considering jointly the influence of individual-level variables, as well as country-level variables, either aggregate from the original household survey or included from other sources (i.e. WGI). This estimation technique is especially recommended when coefficients at the higher level of aggregation are of interest, as standard errors may be severely underestimated otherwise. However, we first estimate a shell-model which includes no explanatory variables beyond the country fixed effects, nor random intercepts coefficients. ${ }^{11}$ This allows us to identify the share of variance explained at the country level and provide an additional justification for our approach. This empty

\footnotetext{
11 In this model where there is no explatory variable, the constant has a coefficient of 5.5 and a standard error of 0.143 . The variance of the constant is 0.72 .
} 
Table 1 Life satisfaction and country level corruption

\begin{tabular}{|c|c|c|c|c|c|c|}
\hline \multirow[t]{2}{*}{ Variables } & \multicolumn{6}{|c|}{ Life satisfaction } \\
\hline & (1) & (2) & (3) & (4) & (5) & (6) \\
\hline \multicolumn{7}{|c|}{ Individual level variables } \\
\hline Age & $\begin{array}{l}-0.031^{* * *} \\
(0.002)\end{array}$ & $\begin{array}{l}-0.031 * * * \\
(0.002)\end{array}$ & $\begin{array}{l}-0.031 * * * \\
(0.002)\end{array}$ & $\begin{array}{l}-0.031 * * * \\
(0.002)\end{array}$ & $\begin{array}{l}-0.031^{* * *} \\
(0.002)\end{array}$ & $\begin{array}{l}-0.0313 * * * \\
(0.00214)\end{array}$ \\
\hline Age squared & $\begin{array}{l}0.0003 * * * \\
(2.22 \mathrm{e}-05)\end{array}$ & $\begin{array}{l}0.000 * * * \\
(2.22 \mathrm{e}-05)\end{array}$ & $\begin{array}{l}0.000 * * * \\
(2.22 \mathrm{e}-05)\end{array}$ & $\begin{array}{l}0.000 * * * \\
(2.22 \mathrm{e}-05)\end{array}$ & $\begin{array}{l}0.000 * * * \\
(2.22 \mathrm{e}-05)\end{array}$ & $\begin{array}{l}0.000337 * * * \\
(2.22 \mathrm{e}-05)\end{array}$ \\
\hline Male & $\begin{array}{l}-0.032 * * * \\
(0.012)\end{array}$ & $\begin{array}{l}-0.032 * * * \\
(0.012)\end{array}$ & $\begin{array}{l}-0.032 * * * \\
(0.012)\end{array}$ & $\begin{array}{l}-0.032 * * * \\
(0.012)\end{array}$ & $\begin{array}{l}-0.032 * * * \\
(0.012)\end{array}$ & $\begin{array}{l}-0.0320 * * * \\
(0.0122)\end{array}$ \\
\hline Work & $\begin{array}{l}0.059 * * * \\
(0.013)\end{array}$ & $\begin{array}{l}0.059 * * * \\
(0.013)\end{array}$ & $\begin{array}{l}0.058 * * * \\
(0.013)\end{array}$ & $\begin{array}{l}0.058 * * * \\
(0.013)\end{array}$ & $\begin{array}{l}0.059 * * * \\
(0.013)\end{array}$ & $\begin{array}{l}0.0590 \text { *** } \\
(0.0137)\end{array}$ \\
\hline High income & $\begin{array}{l}0.790 * * * \\
(0.017)\end{array}$ & $\begin{array}{l}0.790 * * * \\
(0.017)\end{array}$ & $\begin{array}{l}0.790 * * * \\
(0.017)\end{array}$ & $\begin{array}{l}0.790 * * * \\
(0.017)\end{array}$ & $\begin{array}{l}0.790 * * * \\
(0.017)\end{array}$ & $\begin{array}{l}0.790 * * * \\
(0.0178)\end{array}$ \\
\hline Middle income & $\begin{array}{l}0.511^{* * * *} \\
(0.014)\end{array}$ & $\begin{array}{l}0.511 * * * \\
(0.014)\end{array}$ & $\begin{array}{l}0.511 * * * \\
(0.014)\end{array}$ & $\begin{array}{l}0.511^{* * * *} \\
(0.014)\end{array}$ & $\begin{array}{l}0.511^{* * *} \\
(0.014)\end{array}$ & $\begin{array}{l}0.511 * * * \\
(0.0146)\end{array}$ \\
\hline Religion & $\begin{array}{l}0.020 \\
(0.015)\end{array}$ & $\begin{array}{l}0.020 \\
(0.015)\end{array}$ & $\begin{array}{l}0.019 \\
(0.015)\end{array}$ & $\begin{array}{l}0.019 \\
(0.015)\end{array}$ & $\begin{array}{l}0.019 \\
(0.015)\end{array}$ & $\begin{array}{l}0.0200 \\
(0.0159)\end{array}$ \\
\hline Poor health & $\begin{array}{l}-0.279 * * * \\
(0.020)\end{array}$ & $\begin{array}{l}-0.279 * * * \\
(0.020)\end{array}$ & $\begin{array}{l}-0.279 * * * \\
(0.020)\end{array}$ & $\begin{array}{l}-0.279 * * * \\
(0.020)\end{array}$ & $\begin{array}{l}-0.279 * * * \\
(0.020)\end{array}$ & $\begin{array}{l}-0.279 * * * \\
(0.0205)\end{array}$ \\
\hline Married & $\begin{array}{l}0.121^{* * * *} \\
(0.013)\end{array}$ & $\begin{array}{l}0.121 * * * \\
(0.013)\end{array}$ & $\begin{array}{l}0.122 * * * \\
(0.013)\end{array}$ & $\begin{array}{l}0.122 * * * \\
(0.013)\end{array}$ & $\begin{array}{l}0.122 * * * \\
(0.013)\end{array}$ & $\begin{array}{l}0.122 * * * \\
(0.0130)\end{array}$ \\
\hline Higher education & $\begin{array}{l}0.146 * * * \\
(0.017)\end{array}$ & $\begin{array}{l}0.146^{* * * *} \\
(0.017)\end{array}$ & $\begin{array}{l}0.147 * * * \\
(0.017)\end{array}$ & $\begin{array}{l}0.147 * * * \\
(0.017)\end{array}$ & $\begin{array}{l}0.147 * * * \\
(0.017)\end{array}$ & $\begin{array}{l}0.146 * * * \\
(0.0173)\end{array}$ \\
\hline Secondary education & $\begin{array}{l}0.054 * * * \\
(0.016)\end{array}$ & $\begin{array}{l}0.055^{* * *} \\
(0.016)\end{array}$ & $\begin{array}{l}0.055^{* * *} \\
(0.016)\end{array}$ & $\begin{array}{l}0.055 * * * \\
(0.016)\end{array}$ & $\begin{array}{l}0.055^{* * * *} \\
(0.016)\end{array}$ & $\begin{array}{l}0.0555 * * * \\
(0.0163)\end{array}$ \\
\hline Father education & $\begin{array}{l}0.004 * * \\
(0.001)\end{array}$ & $\begin{array}{l}0.003 * * \\
(0.001)\end{array}$ & $\begin{array}{l}0.003 * * \\
(0.001)\end{array}$ & $\begin{array}{l}0.003 * * \\
(0.001)\end{array}$ & $\begin{array}{l}0.003 * * \\
(0.001)\end{array}$ & $\begin{array}{l}0.00396 * * \\
(0.00167)\end{array}$ \\
\hline Local admin & $\begin{array}{l}0.074 * * * \\
(0.007)\end{array}$ & $\begin{array}{l}0.073 * * * \\
(0.007)\end{array}$ & $\begin{array}{l}0.073 * * * \\
(0.007)\end{array}$ & $\begin{array}{l}0.073 * * * \\
(0.007)\end{array}$ & $\begin{array}{l}0.073 * * * \\
(0.007)\end{array}$ & $\begin{array}{l}0.0736 * * * \\
(0.00794)\end{array}$ \\
\hline National admin & $\begin{array}{l}0.139 * * * \\
(0.008)\end{array}$ & $\begin{array}{l}0.139 * * * \\
(0.008)\end{array}$ & $\begin{array}{l}0.140 * * * \\
(0.008)\end{array}$ & $\begin{array}{l}0.140 * * * \\
(0.008)^{* * *}\end{array}$ & $\begin{array}{l}0.140 * * * \\
(0.008)\end{array}$ & $\begin{array}{l}0.140 * * * \\
(0.008)\end{array}$ \\
\hline \multicolumn{7}{|l|}{ Country level variables } \\
\hline West Europe & & $\begin{array}{l}0.474 * * * \\
(0.115)\end{array}$ & & $\begin{array}{l}0.348 * * \\
(0.159)\end{array}$ & & $\begin{array}{l}0.430 * * * \\
(0.144)\end{array}$ \\
\hline Control of corruption & & & $\begin{array}{l}0.172 * * * \\
(0.048)\end{array}$ & $\begin{array}{l}0.072 \\
(0.064)\end{array}$ & & \\
\hline Governance index & & & & & $\begin{array}{l}0.150 * * * \\
(0.058)\end{array}$ & $\begin{array}{l}0.034 \\
(0.065)\end{array}$ \\
\hline Constant & $\begin{array}{l}2.602 * * * \\
(0.074)\end{array}$ & $\begin{array}{l}2.536 * * * \\
(0.070)\end{array}$ & $\begin{array}{l}2.618 * * * \\
(0.069)\end{array}$ & $\begin{array}{l}2.560 * * * \\
(0.073)\end{array}$ & $\begin{array}{l}2.584 * * * \\
(0.071)\end{array}$ & $\begin{array}{l}2.538 * * * \\
(0.070)\end{array}$ \\
\hline Random effect & & & & & & \\
\hline Variance constant & .078 & .054 & .057 & .051 & .065 & .053 \\
\hline Variance residual & $(.019)$ & $(.013)$ & $(.014)$ & $(.012)$ & $(.016)$ & $(0.131)$ \\
\hline Var (res) & $\begin{array}{l}.865 \\
(.007)\end{array}$ & $\begin{array}{l}.865 \\
(.007)\end{array}$ & $\begin{array}{l}.865 \\
(.007)\end{array}$ & $\begin{array}{l}.865 \\
(.007)\end{array}$ & $\begin{array}{l}.886 \\
(.007)\end{array}$ & $\begin{array}{l}.886 \\
(.007)\end{array}$ \\
\hline
\end{tabular}


Table 1 (continued)

\begin{tabular}{lllllll}
\hline Variables & \multicolumn{6}{l}{ Life satisfaction } \\
\cline { 2 - 7 } & $(1)$ & $(2)$ & $(3)$ & $(4)$ & $(5)$ & $(6)$ \\
\hline Observations & 24,169 & 24,169 & 24,169 & 24,169 & 24,169 & 24,169 \\
Number of groups & 35 & 35 & 35 & 35 & 35 & 35 \\
\hline
\end{tabular}

Standard errors in parentheses; age is the individual age in year; work is dummy variable for work status; high income and middle income are dummy variables for income level; poor health is a dummy variable for health problems; married is a dummy variable for marital status; higher education and secondary education are dummies variable for education level; father education is a dummy variable taking one if the father has a high education level; local admin and national administration are dummies variable taking value one if the individual is satisfied with the local and national administration; political connection is a dummy variable taking value one if political connection is considered more important then merit; control of corruption is the corruption indicator form the World Bank Governance dataset; governance index is aggregate World Bank Governance indicator

$* * * p<0.01 ; * * p<0.05 ; * p<0.1$

model shows that about $8 \%$ of the total variance in the sample is explained at the country level, confirming the relevance of a multilevel analysis.

In a second step, we add our full list of individual controls. A log-likelihood ratio test ${ }^{12}$ confirms the superiority of this second model over our empty model, and $8 \%$ of the variance remains explained by our country-specific intercepts (see model 1 in Table 1).

Our selection of individual-level variable is very close to Djankov et al. (2016) and includes individual-level controls, which are standard in the literature. In particular, we control for age, gender, marital and employment status, income class, health, religiosity, individual and parental education, and finally an indicator of the respondent's satisfaction with local and national administration. It is reassuring that in all estimations both the sign and magnitude of the aforementioned controls are in line with the existing literature. We find that being employed, participating in religious activity, being married and satisfied with local and national administration are characteristics associated with greater levels of well-being. For what concerns the role of the life cycle, the literature has often found a $\mathrm{U}$ shape relationship between age and life satisfaction (see for instance Blanchflower and Oswald 2008 or Frijters and Beatton 2008), hence we include age and its square term. In line with existing studies, we find evidence for a non-linear effect of age on subjective welfare, with older and younger individuals being happier than middle-aged respondents. Being in bad health is associated with significantly lower life satisfaction (see Sanfey and Teksoz 2007 for a discussion of the standard correlates of happiness in post-communist Eastern Europe).

\subsection{Adding Country-Level Explanatory Variables}

We then turn to our country-level variables. We first want to confirm the existence of a happiness gap between Eastern and Western European countries, we thus add a dummy taking value one for all non-Eastern European countries in the sample. This is reported

\footnotetext{
12 It is worth specifying that we are testing that the empty model is nested in the second richer one. The result of the test is : LR chi2 $(15)=4276.59$; Prob $>$ chi $2=0.0000$.
} 
in the second column in Table 1. A log-likelihood ratio test does confirm that this new variable is improving the fit of our model. ${ }^{13}$ Additionally, the dummy is positive and highly significant, thus confirming the existence of a happiness gap in Eastern Europe, in this dataset collected in 2010 .

In a third model we include the Control of Corruption (from the World Bank Governance Indicators), instead of the west Europe dummy. This variable is also positively and significantly associated with life satisfaction and its contribution to the explanatory power of our model is confirmed through a log-likelihood ratio test. ${ }^{14}$

In column four, we jointly include "control-of-corruption" and the west Europe dummy, and find that both variables have the expected sign but only west Europe is significant. However the fit of the model is no better than when we only include control-of-corruption. We can thus conclude that institutional quality explains an important share of the Eastern European happiness gap, but it seems to be mostly via corruption. Similarly in column five and six, we repeat the same procedure by controlling for the World Bank Governance Index (WGI) instead of its corruption sub-index. The results indicate once again that better institutions are associated with higher level of life satisfaction. When controlling for WGI as well as the West Europe dummy, such a variable is not significant. Moreover including the "control-of-corruption" sub-element of the WGI appears to increase the fit of the model more than the aggregate index. This is in line with Djankov et al. (2016) and consistent with Fidrmuc and Gërxhani (2008), who had similarly found that the social capital gap between East and West was wiped out by institutional quality.

The role of corruption in explaining part of the happiness gap is also confirmed when aggregate corruption measures from the LITS are included in the model, namely countrylevel average of perception on bribing (bribes paid by "someone like me"), experience of bribing and importance of political connections. The results show that the estimated coefficients for perceived corruption and political connection are negative and significant, and negative but below standard-level of significance for corruption victimisation (results are reported in Table 2). Overall our analysis already provides some support for $\mathrm{H} 1 \mathrm{~b}$, namely that higher levels of corruption measured at country-level, is associated with lower subjective well-being.

\subsection{Exploring the Role of Corruption: Do People Adapt to Corrupt Practices?}

In Table 3, we test the impact of individual-level corruption (H1a) and the adherence hypothesis $(\mathrm{H} 2)$ by examining the interplay between one's experience or perception of corruption and country-level corruption. In these models, we explore the interplay between individual corruption measures (i.e. political connection, perception of corruption and victimisation) and their country-level average on life satisfaction. To test the adaptation hypothesis we add an interaction term between each corruption measures and its countrylevel average. In column one, we control for all the corruptions measures and their interactions with their respective average at once. The results reported in column one show that both the individual-level measures, as well as the contextual-level measures of corruption

\footnotetext{
13 We test the model in column one versus a model with the west europe dummy: LR chi2(1)=13.85, Prob $>$ chi $2=0.0002$.

14 We test the model in column one versus a model with control of corruption: LR chi2 $(1)=10.57$, Prob $>$ chi $2=0.0012$.
} 
Table 2 Life satisfaction and country level corruption

\begin{tabular}{|c|c|c|c|}
\hline \multirow[t]{2}{*}{ Variables } & \multicolumn{3}{|c|}{ Life satisfaction } \\
\hline & $(1)$ & (2) & (3) \\
\hline \multicolumn{4}{|l|}{ Individual level variables } \\
\hline Age & $\begin{array}{l}-0.031 * * * \\
(0.002)\end{array}$ & $\begin{array}{l}-0.031 \text { *** } \\
(0.002)\end{array}$ & $\begin{array}{l}-0.031^{* * *} \\
(0.002)\end{array}$ \\
\hline Age squared & $\begin{array}{l}0.000^{* * *} \\
(2.22 \mathrm{e}-)\end{array}$ & $\begin{array}{l}0.0003 * * * \\
(2.22 \mathrm{e}-)\end{array}$ & $\begin{array}{l}0.000^{* * * *} \\
(2.22 \mathrm{e}-)\end{array}$ \\
\hline Male & $\begin{array}{l}-0.031 \text { *** } \\
(0.012)\end{array}$ & $\begin{array}{l}-0.031 \text { *** } \\
(0.012)\end{array}$ & $\begin{array}{l}-0.032^{* * *} \\
(0.012)\end{array}$ \\
\hline Work & $\begin{array}{l}0.059 * * * \\
(0.013)\end{array}$ & $\begin{array}{l}0.059 * * * \\
(0.013)\end{array}$ & $\begin{array}{l}0.059 * * * \\
(0.013)\end{array}$ \\
\hline High income & $\begin{array}{l}0.791 * * * \\
(0.017)\end{array}$ & $\begin{array}{l}0.790 * * * \\
(0.017)\end{array}$ & $\begin{array}{l}0.790 * * * \\
(0.017)\end{array}$ \\
\hline Middle income & $\begin{array}{l}0.511 * * * \\
(0.014)\end{array}$ & $\begin{array}{l}0.511 * * * \\
(0.014)\end{array}$ & $\begin{array}{l}0.511 * * * \\
(0.014)\end{array}$ \\
\hline Religion & $\begin{array}{l}0.021 \\
(0.015)\end{array}$ & $\begin{array}{l}0.020 \\
(0.015)\end{array}$ & $\begin{array}{l}0.020 \\
(0.015)\end{array}$ \\
\hline Poor health & $\begin{array}{l}-0.280 * * * \\
(0.020)\end{array}$ & $\begin{array}{l}-0.279 * * * \\
(0.020)\end{array}$ & $\begin{array}{l}-0.279 \text { *** } \\
(0.020)\end{array}$ \\
\hline Married & $\begin{array}{l}0.121 * * * \\
(0.013)\end{array}$ & $\begin{array}{l}0.121 * * * \\
(0.013)\end{array}$ & $\begin{array}{l}0.121^{* * *} \\
(0.013)\end{array}$ \\
\hline Higher education & $\begin{array}{l}0.145 * * * \\
(0.017)\end{array}$ & $\begin{array}{l}0.146 * * * \\
(0.017)\end{array}$ & $\begin{array}{l}0.146 * * * \\
(0.017)\end{array}$ \\
\hline Secondary education & $\begin{array}{l}0.054 * * * \\
(0.016)\end{array}$ & $\begin{array}{l}0.054 * * * \\
(0.016)\end{array}$ & $\begin{array}{l}0.054 * * * \\
(0.016)\end{array}$ \\
\hline Father education & $\begin{array}{l}0.004^{* *} \\
(0.001)\end{array}$ & $\begin{array}{l}0.004 * * \\
(0.001)\end{array}$ & $\begin{array}{l}0.004 * * \\
(0.001)\end{array}$ \\
\hline Local admin & $\begin{array}{l}0.073 * * * \\
(0.007)\end{array}$ & $\begin{array}{l}0.073 * * * \\
(0.007)\end{array}$ & $\begin{array}{l}0.074 * * * \\
(0.007)\end{array}$ \\
\hline National admin & $\begin{array}{l}0.139 * * * \\
(0.008)\end{array}$ & $\begin{array}{l}0.139 * * * \\
(0.008)\end{array}$ & $\begin{array}{l}0.139 * * * \\
(0.008)\end{array}$ \\
\hline \multicolumn{4}{|l|}{ Country level variables } \\
\hline Political connection mean & $\begin{array}{l}-0.886^{* * *} \\
(0.328)\end{array}$ & & \\
\hline Perceived corruption mean & & $\begin{array}{l}-0.0208^{*} \\
(0.0115)\end{array}$ & \\
\hline Victimisation mean & & & $\begin{array}{l}-0.140 \\
(0.143)\end{array}$ \\
\hline Constant & $\begin{array}{l}2.835 * * * \\
(0.112)\end{array}$ & $\begin{array}{l}2.720 * * * \\
(0.098)\end{array}$ & $\begin{array}{l}2.646 * * * \\
(0.086)\end{array}$ \\
\hline \multicolumn{4}{|l|}{ Random effect } \\
\hline Variance constant & .068 & .075 & .080 \\
\hline Variance residual & .869 & .869 & .869 \\
\hline Observations & 25,246 & 25,246 & 25,246 \\
\hline Number of groups & 35 & 35 & 35 \\
\hline
\end{tabular}


Table 2 (continued)

\begin{abstract}
Standard errors in parentheses; age is the individual age in year; work is dummy variable for work status; high income and middle income are dummy variables for income level; poor health is a dummy variable for health problems; married is a dummy variable for marital status; higher education and secondary education are dummies variable for education level; father education is a dummy variable taking one if the father has a high education level; local admin and national administration are dummies variable taking value one if the individual is satisfied with the local and national administration; "Perceived Corruption Mean" is the country level average of how likely it is that bribery will be paid by "someone like me" when trying the access a public service; Victimisation Mean is the country average of a variable which sums scores measuring how often it is that 'unofficial payment' will be paid by "someone like me"
\end{abstract}

$* * * p<0.01 ; * * p<0.05 ; * p<0.1$

matter and are negatively associated with life satisfaction. Interestingly, the effect of perception of corruption is significantly moderated by its country level average. Such an effect is small but significant and hence in line with our expectation of a positive mitigating effect of aggregate corruption. However, political connection shows no significant mitigating effect, while we find such a moderating effect for victimisation, but of the wrong sign (although it is also of very small magnitude).

However, the information captured by our different measures of corruption is expected to be at least partly redundant. In column two to four, we thus repeat the same exercise with just one measure of corruption at a time. The models estimated in columns two and three show some evidence in support of the adherence hypothesis, as both the negative effect of political connections and perception of corruption are diminished by higher level of contextual corruption. However in column four when we control for victimisation and its interaction with the country average, the sign of the interaction term doesn't support the adherence hypothesis. Moreover the victimisation variable appears insignificant. The LR test indicates that the cross level interactions analysed in column two and four improve the fitness of the model. ${ }^{15}$ Overall, such a result supports hypotheses H1a and H1b for both political connection and perceived corruption, but not for victimisation, which appears instead unrelated to life satisfaction, both when measured at the individual or aggregated level. We also find support for $\mathrm{H} 2$ when we control for political connection and perceived corruption only. However, the coefficients estimated for individual, and aggregate levels of perceived corruption and their interaction are of limited magnitude, and LR-test indicates that the specifications without interaction term fits our data better.

To summarise these results more clearly, we can plot the estimated marginal effects of individual-level corruption as aggregate corruption increases for each of our measures of corruption, as done in Figs. 1, 2 and 3 presented in the "Appendix".

Figure 1 represents graphically the results of the second column of Table 3, and it offers a visualisation of how individual recognition of the importance of political connection affects wellbeing in our sample, as the aggregate level of this variable increases. We can see that the perception that one needs political connections lowers life satisfaction, but

\footnotetext{
15 Testing model one versus a model with no interactions: $L R$ chi $2(1)=3.10 ;$ Prob $>$ chi $2=0.0784$ Testing model two versus a model with no interactions: $L R$ chi2 $(1)=35.76$, Prob $>$ chi $2=0.0000$ Testing model three versus a model with no interactions: $L R$ chi2 $(1)=3.4$, Prob $>\operatorname{chi} 2=0.0651$ Testing model four versus a model with no interactions: $L R$ chi2 $(3)=42.63$, Prob $>$ chi $2=0.0000$.
} 
Table 3 Life satisfaction and adaptation to corruption

Variables Life satisfaction
(1)
(2)
(3)
(4)

Individual level variables

Political connection

$-0.261^{* * *}$

$-0.278^{* * *}$

Perceived corruption

$(0.039)$

(0.035)

$-0.012 * * *$

$-0.014 * * *$

$(0.002)$

$(0.001)$

Victimisation

0.010

$-0.026$

$(0.018)$

$(0.015)$

Country level variables

Political connection mean

$-1.082^{* * * *}$

$-1.073^{* * *}$

(0.302)

(0.322)

Perceived corruption mean

$-0.040 * *$

$-0.032^{* * *}$

(0.017)

(0.011)

0.133

0.005

(0.216)

Interactions terms

Political connection*mean

\subsection{7}

$0.182 *$

(0.114)

(0.103)

Perceived corruption*mean

$0.001 * * *$

$0.0013^{* * *}$

$(0.000)$

Victimisation*mean

$-0.076^{* * * *}$

$(0.000)$

$-0.035^{*}$

(0.023)

(0.020)

Random effects

Variance constant

$\begin{array}{ll}0.043 & 0.050 \\ 0.894 & 0.906 \\ 21,936 & 26,738\end{array}$

0.066

0.066

Variance residual

26,738

0.905

0.908

Observations

21,936

23,649

27,251

Standard errors in parentheses; all specifications include the standard individual level controls reported in Tables 1 and 2. Political connection is a dummy variable taking value one if political connection is considered more important than merit; political connection mean is the country average of political connection; perceived corruption is the average of how likely it is that bribery will be paid by "someone like me" when trying the access a public service; perceived corruption mean is the country average of perceived corruption; victimisation is a variable which sums scores measuring how often it is that 'unofficial payment' will be paid by "someone like me"; victimisation mean is the country average of victimisation

$* * * p<0.01 ; * * p<0.05 ; * p<0.1$

slightly less so when the practice is perceived to be more pervasive (in line with the significant and positive interaction term estimated). However, it also clearly illustrates the heavy cost associated with higher aggregate level of corruption (aggregate reliance on political connections) over the region, a cost very far from being offset by the small positive interaction terms we identified. In other words, even though we do identify a positive and significant interaction term between individual and country levels measures of importance of political connection, and thus confirm our hypothesis $\mathrm{H} 2$ for this measure of corruption, the magnitude of the adherence effect estimated is completely dwarfed by the direct negative cost associated with greater aggregate corruption. 


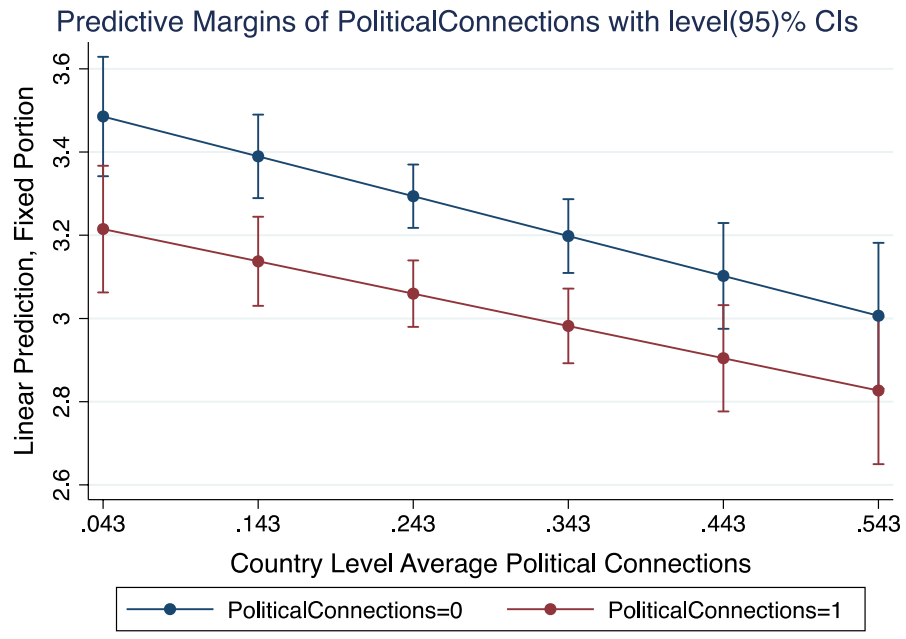

Fig. 1 Interaction between the two values of political connections and the average country level political connection (as reported in Table 3, column 2)

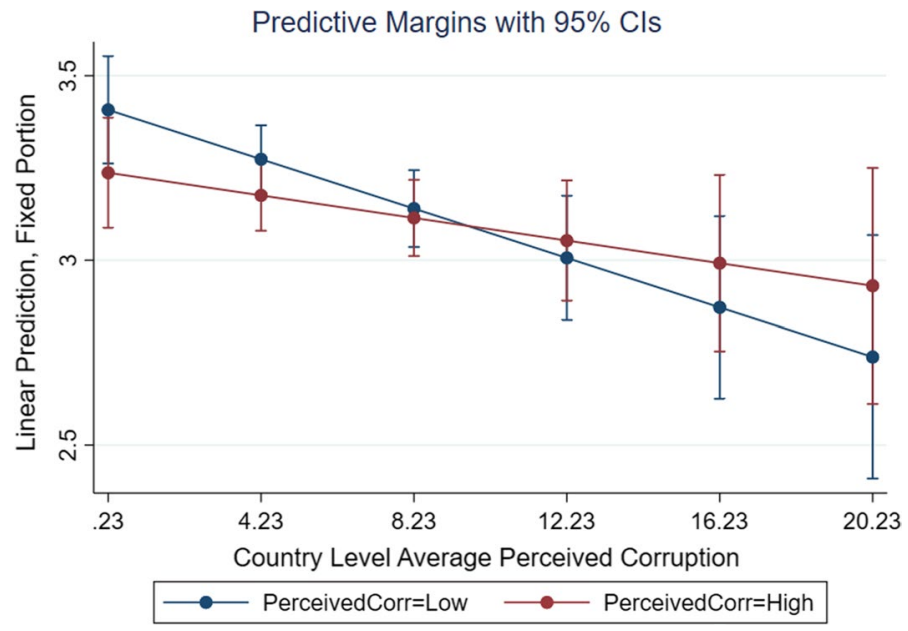

Fig. 2 Interaction between individual level perception of corruption at its bottom and top 10th centile values and the average country level perception of corruption (as reported in Table 3, column 3)

For perceived corruption measured as bribed paid by others like me, Fig. 2 reinforces the already noted small magnitude of the coefficients estimated. The difference in life satisfaction between respondents with low (bottom 10\% of the distribution) or high (top 10\% of the distribution) individual perception of bribe paying by others like them thus translates as too small to be significant once the marginal effects are computed, and this is true at all levels of aggregated corruption - thus nuancing the significance of the adherence hypothesis in this case. Finally, any changes in this difference along the distribution of aggregate corruption are again small compared to the decreasing level of life satisfaction directly associated with increasing aggregate levels of corruption. 


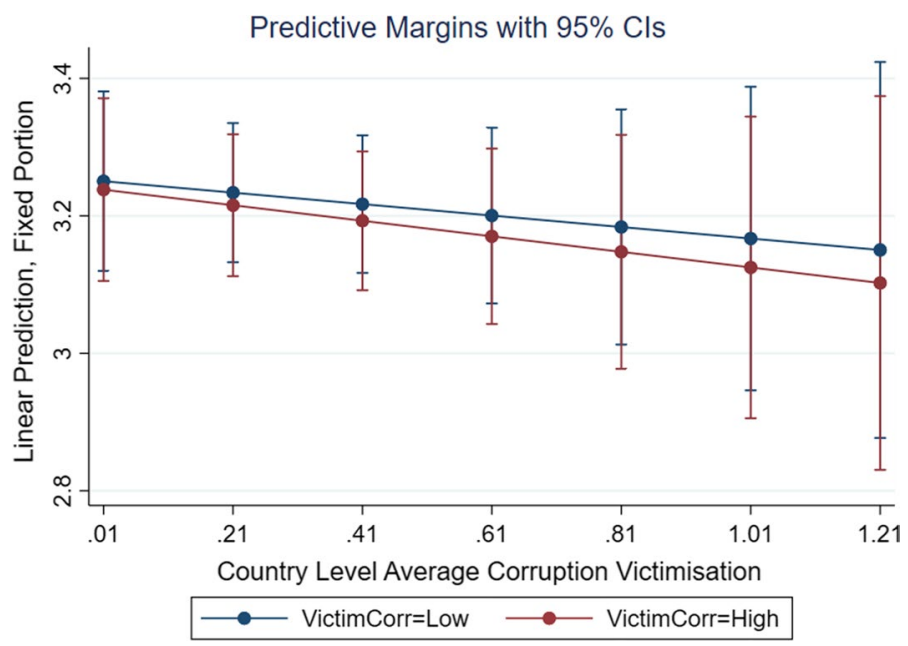

Fig. 3 Interaction between individual level victimisation of corruption at its bottom and top $10^{\text {th }}$ centile values and the average country level victimisation of corruption (as reported in Table 3, column 4)

For victimisation, we found both individual and aggregate levels of corruption to be insignificant. This could be argued to suggest that paying a bribe thus generate benefits that neutralise the related costs incurred. However, and as noted in the literature, self-reported bribe paying is often biased as most respondents would be uncomfortable reporting illicit practices (e.g. Djankov et al. 2016). Here we show that those reporting their own bribe paying may be those who are less psychology affected by corruption.

For the rest of the paper we will thus focus on perception of corruption measured through reliance on political connection and bribes paid by others, as these are the 2 only variables for which we identified a potential (albeit small) social norm effects. We note again that this is a common approach in the literature on life satisfaction and corruption (see Wu and Zhu 2016 or Djankov et al. 2016).

\subsection{Exploring the Role of Corruption: Is There a Differential Impact of Corruption Across Different Groups?}

We now turn our discussion to possible heterogeneous effects of corruption on life satisfaction in different groups, to test our third hypothesis ( $\mathrm{H} 3 \mathrm{a}$ and $\mathrm{H} 3 \mathrm{~b}$ ).

Table 4 explores the relationship between income, education and corruption and their effect on life satisfaction. For conciseness, the table only shows the main variables of interest namely, income, education, corruption and their interactions. Two dummy variables are used to capture individuals' income level, one takes a value of 1 for high-income individual and the other one for middle income. So in this instance the omitted category is low income. The results show that, as expected, having a high or medium income has a significant and positive effect on life satisfaction. This appears to be in line with the microeconomic literature discussing the income-subjective well-being relation (e.g. Dolan et al. 2008). In column one, we also include two interaction terms between the income dummies and political connection. The results show that greater corruption, as measured for instance by the average of political connection, enhances the positive effect of being rich on life satisfaction (column one). This result is reported graphically in Fig. 4 in the "Appendix". The figure clearly 


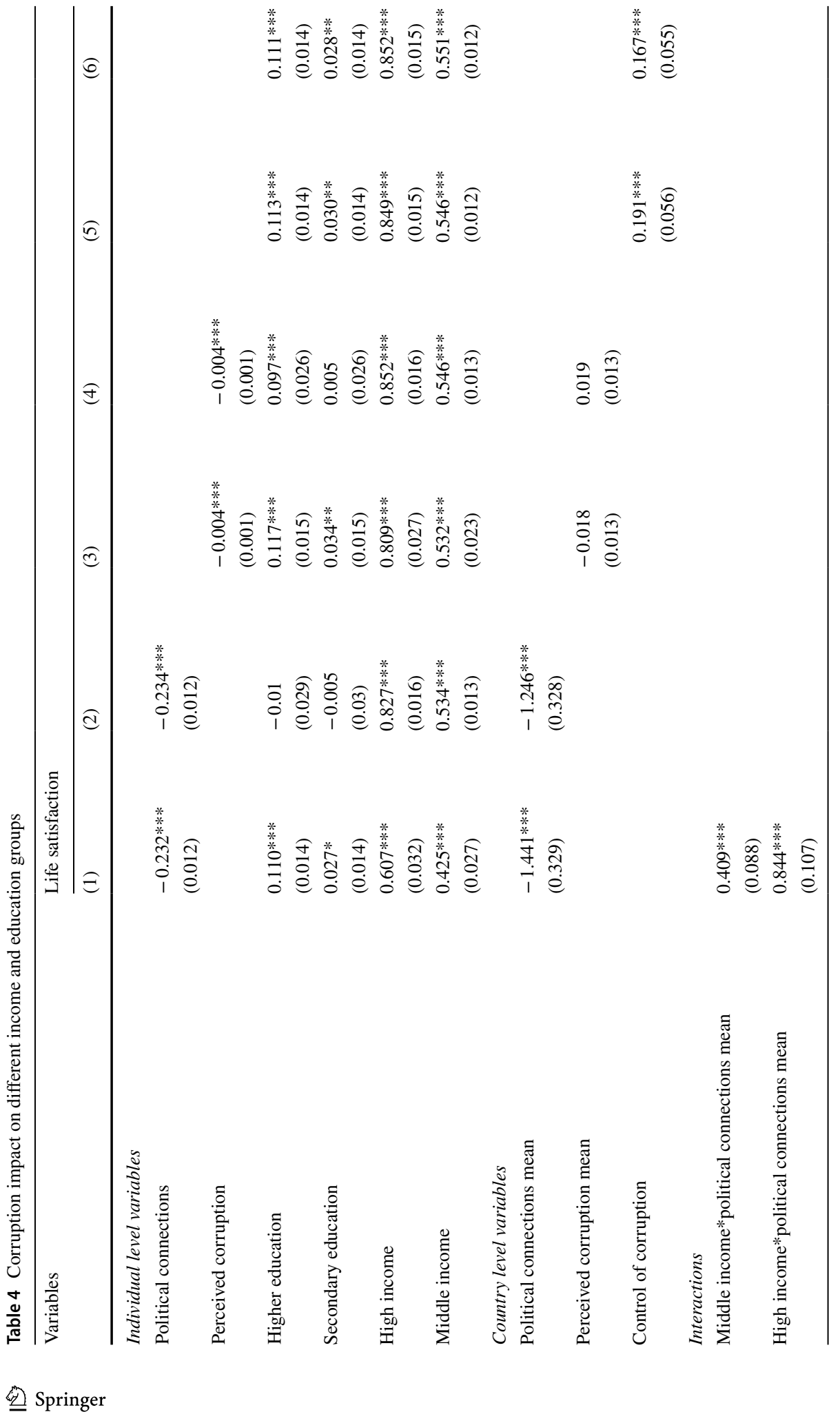




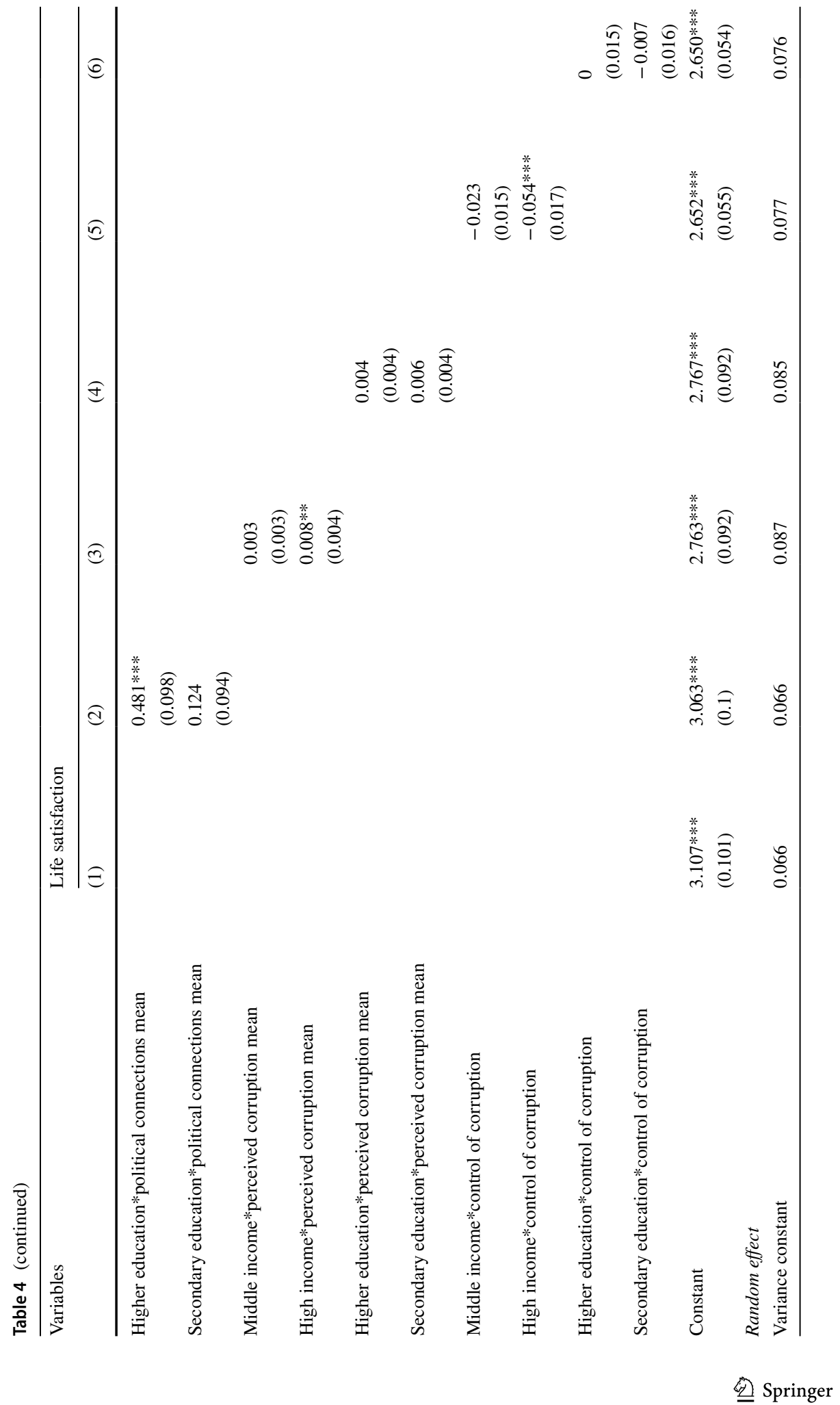




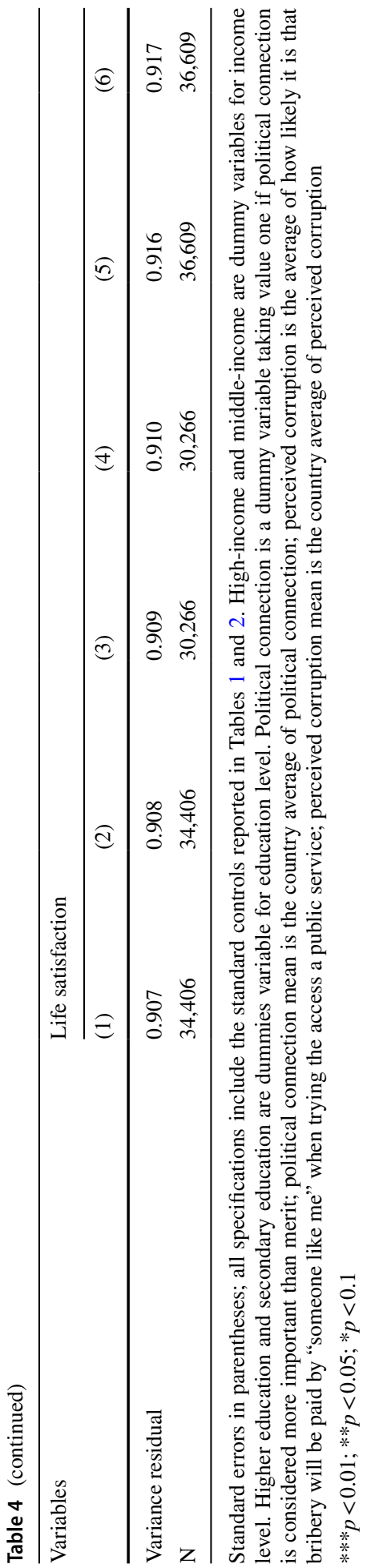




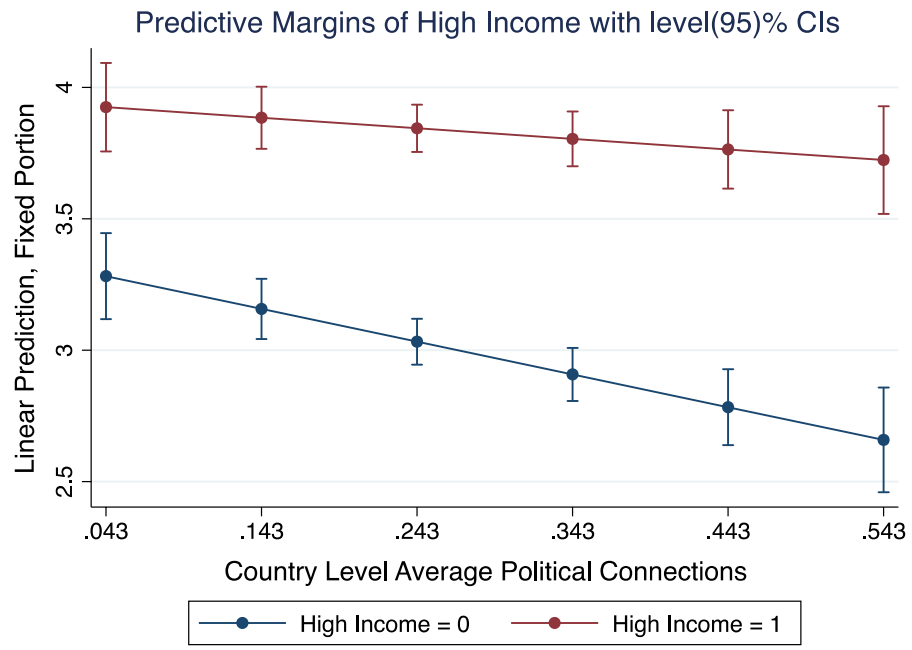

Fig. 4 Interaction between high income dummy and the average country level of political connection (as reported in Table 4, column 1)

\section{Predictive Margins of Higher Education with level(95)\% Cls}

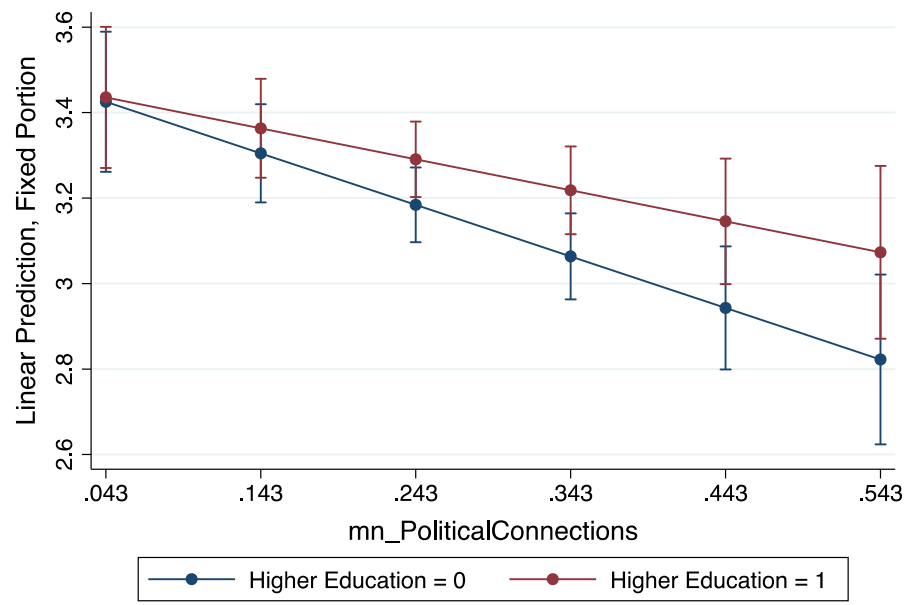

Fig. 5 Interaction between higher education dummy and the average country level of political connection (as reported in Table 4, column 2)

shows that high-income individuals have significantly higher level of well-being at any level of corruption. However, the well-being gap between different income groups increases with the aggregate corruption level (it roughly doubles from the bottom 10 to the top 10 centiles of the distribution of aggregate corruption in our sample). In column two, we analyse the interaction between country level of corruption and one's education attainment. The effect of education is captured using three mutually exclusive dummy variables reporting the highest level of education achieved: i.e. primary school only, secondary education or tertiary 
education. The primary school dummy is our reference category. As expected, individual with secondary or tertiary education have a greater level of well-being compared to those that only studied up to primary school. The sign of the interaction terms shows that higher corruption enhances the positive impact of higher education on subjective well-being. The marginal effect of higher education on well-being conditional on country-level corruption is illustrated in Fig. 5 in the "Appendix". Overall, the interplay between corruption and education shows similar patterns to what was discussed in the context of the income-corruption relationship. In columns three and four, we explore the interaction between perceived corruption and income and education, there, the interaction with high income is significant at $5 \%$ while the interactions with education levels are not significant. Finally in column five and six, we repeat the same exercise including control of corruption from the WGI. The latter is positive and significant as expected, so greater control of corruption is significantly associated with greater life satisfaction. Moreover the interaction terms are negative, although the effect of corruption seems to be significantly affected only by income (column 5 ) and not by education (column 6). As shown in column 5, being rich decreases the positive impact of better control of corruption on well-being.

Again, we use the LR test to get a sense of whether the interactions analysed in Table 4 improve the fitness of the model. In this instance, the LR tests support the inclusion of the interaction between political connection and income and education, and between control of corruption and income (i.e. model reported in column one, two, and five.). ${ }^{16}$ In those cases, the interaction term explored significantly improves the fitness of the model. Overall the analysis carried out in this section provides support for the testable hypothesis H3, when corruption is measured as reliance on political connection ( $\mathrm{H} 3 \mathrm{a}$ and $\mathrm{H} 3 \mathrm{~b})$ or as the inverse of the World Bank "control of corruption" variable (H3a only).

This is an important result especially in light of the well-known impact of corruption on income inequality. Macroeconomic studies have argued that corruption tends to preserve or even widen income inequalities ( $\mathrm{Li}$ et al. 2000). Such an effect may happen through several channels. For example greater corruption tends to lower growth and the povertyreducing power of growth (Ravallion and Chen 1997), or may bias the tax system, social programs (Rose-Ackerman 1997) and asset ownership (Birdsall and Londono 1997). Our findings highlight that corruption contributes to creating further non-monetary inequality, as wealthier individuals are better able to exploit opportunities and extract greater levels of life satisfaction compared to poorer ones.

\subsection{Random Slope Models}

In order to model the fact that the relationship between life satisfaction and corruption is context specific, we also estimate a specification where each country has its own intercept as well as slope. So not only the average well-being varies across countries, but also its responsiveness to corruption. We measure corruption with the three variables discussed above, (i.e. political connections, perceived corruption and the victimisation index) and estimate three models with a random slope for each of the corruption indicator. The results

\footnotetext{
16 Testing model one versus a model with no interactions: LR chi2 2 (2) $=62.69$, Prob $>$ chi $2=0.0000$

Testing model two versus a model with no interactions: $L R$ chi2 $(2)=26.16$, Prob $>$ chi $2=0.0000$

Testing model three versus a model with no interactions: $L R$ chi2 $(2)=4.02$, Prob $>$ chi2 $=0.1339$

Testing model four versus a model with no interactions: $L R$ chi2 $(2)=1.86$, Prob $>\operatorname{chi} 2=0.3950$

Testing model five versus a model with no interactions: $L R$ chi2 $(2)=10.73$, Prob $>$ chi $2=0.0047$

Testing model six versus a model with no interactions: $L R$ chi $2(2)=0.25$, Prob $>$ chi $2=0.8806$.
} 
on our main control variables are consistent with results reported in Table 1. Political Connection is again negative and strongly significant, however perceived corruption and victimisation are negative but not significant. Overall these findings show that the inclusion of a random slope offers additional support for a context-specific effect of individual experience or perception of corruption as posited in $\mathrm{H} 2$ and $\mathrm{H} 3$.

These results, reported in "Appendix" in Table 8, thus confirm that it is reasonable to expect that the response to corruption differs by country, and provide some additional justification for the models we presented in the previous section investigating cross-level interactions.

\section{Robustness}

To further validate our results, in separate regressions, we split the sample by gender, age groups, education, and income group. This allows us to investigate whether particular sociodemographic characteristics are driving the results. We test the robustness of the findings on the adaptation hypothesis (H2). We report these checks based on the replication of the specification in the second column of Table 3 where we measure corruption with the variable "Political Connections". The relevant results are reported in Table 9 in "Appendix", where estimates by income level, by education level, by gender and by age group are reported.

In line with our main results, political connection and its country level average have a negative impact on individual well-being. The interaction term between individual perception and country-level aggregate are now insignificant for all groups, except higher income and older respondents, demonstrating that if social norm exists they are limited to specific sub-group in the population.

Second in Table 10, we run similar robustness checks on the results reported in Table 4. In this instance, we are interested in the interplay between the average corruption level and individual levels of income and education. Since we now focus on income and education level, we only split the sample by gender and age group. As above, we report results using the importance of political connections as our measure of corruption. The estimates reported in "Appendix" show that higher corruption enhances the positive impact of higher education in all sub-sample, except the group of older respondents, and while middle and high income has a positive effect on subjective well-being for all sub-sample.

Finally in Tables 11 and 12, we replicate the results of Tables 1 and 3 but we also include the Gini index and the logarithm of GDP per capita as additional controls (measured in constant 2009 US dollar to avoid endogeneity issues) as potential confounding factor at the aggregate level. The GDP per capita clearly matters at least to the extent that corruption does correlate with level of development. However, we should note that our data was collected in 2010 and GDP levels were profoundly disrupted by the 2008 economic crisis (for example in the Baltic states, some of the worth affected countries in eastern Europe, GDP went down by 10-15 percentage point between 2008 and 2010). The results in Table 11 show that the coefficient of GDP per capita is mostly positive but insignificant. Moreover GDP level does not wipe out the contribution of corruption, such a result is in line with Djankov et al. (2016). For what concerns inequality, as measured by the Gini index, we estimate a negative effect, as expected, but the coefficient estimated is mostly insignificant. This is not surprising, as in what is probably the most thorough analysis to date of inequality in Eastern Europe, Cojocaru (2014) shows that inequality measured through a Gini coefficient is irrelevant to life satisfaction. The coefficients of the corruption indicator employed are smaller when including additional controls however corruption remains significant. Overall, 
Table 12 shows that when controlling for inequality and the level of development, our results on the impact of corruption on well-being and the adaptation hypothesis remain consistent.

\section{Conclusions}

Psychologists, economists and social scientists have much debated what makes people happy. Individual characteristics and key life events are obvious candidates. Happiness studies, a fertile ground of research, have shown that marriage, spirituality, education, being employed and in good health are just some examples of what positively contributes to one's subjective well-being. Aside from individual features, scholars have also been interested in how regional and countrylevel characteristics affect personal well-being. An interesting debate in this area revolves around the apparent happiness gap between Eastern European countries and Western ones. While it is well-known that the economic and social disruption associated with the process of post-communist transformation had far reaching repercussion on well-being, it is far from clear why, as economies recovered starting from the mid-1990s or early 2000s, subjective well-being initially failed to catch-up, generating a happiness gap that persisted until as late as 2015-2016. Various explanations are found in the literature for this gap in subjective well-being between Eastern and Western Europe. But recent studies have shown that institutional quality, and in particular corruption differentials were important explanatory factors (Djankov et al. 2016; Rodríguez-Pose and Maslauskaite 2012). This study re-examines the relationship between subjective well-being and corruption in a sample of Eastern and Western European countries.

We use data from the 2010 round of the Life in Transition survey collected by the EBRD to examine the effect of corruption on life satisfaction. Our results show substantial differences in subjective well-being between Eastern and Western Europe. In line with Djankov et al. (2016) or Rodríguez-Pose and Maslauskaite (2012), we find that this gap is partly explained by aggregate corruption. However, we propose a more nuanced analysis of the role of corruption looking into individual-level measures of corruption, aggregate measures and their interactions. These analyses reveal that individual-level measures of both experienced and perceived corruption have a significant and negative impact of subjective well-being. They also allow us to bring a novel contribution to the literature by examining channels through which corruption may influence subjective well-being.

The first channel analysed here is the interplay between individual and aggregate corruption. Our analyses, indeed, aim to test the adherence hypothesis stating that the impact of corruption on well-being is influenced by behavioural social norms. It is worth mentioning that such proposition has never been tested on Eastern European countries. Our results provide some evidence in support of the adherence hypothesis regarding corruption perception measured as the degree to which the respondent think other like them pay bribes or as the extent to which political connections are believed to help personal success, however the magnitude of this effect is very small, and in particular does not compensate for the direct negative cost associated with increasing aggregate levels of corruption. This stands in contrast to similar analyses conducted in China and Latin America where adherence was shown to reduce significantly the wellbeing cost associated with paying bribes (Wu and Zhu 2016; Graham 2011 respectively). Wu and Zhu (2016) for example concluded that in the most corrupt provinces of China, the wellbeing cost of individual corruption (measured as corruption experienced by people around you) was actually nil. However, the low level of adherence demonstrated here is consistent with the evidence presented on the "Eastern Happiness Gap", which suggests that increasing levels of corruption are associated with greater level of unhappiness in the 
region. We demonstrate here that corruption in Central and Eastern Europe does reduce life satisfaction both through its abstract impact on institutional quality (aggregate levels of corruption) but also through the personal costs it imposes on individuals.

Our results relating to corruption measured as "experienced corruption", as in people reporting directly their own bribe paying, further indicate that for at least a sub-group of respondents, corruption imposes much lower wellbeing cost. Indeed, for this measure of corruption, we estimate virtually nil wellbeing cost at the individual level on average, and very small costs associated with increasing aggregate corruption. This implies a great heterogeneity in the lived experience of corruption in the population, whereby those most willing to report their own corrupt practices do not seem to mind corruption very much, while those reporting corruption practices more indirectly, as practices of people "like me" or as external constraints (i.e. reliance on political connections) suffer more as their personal perception of corruption increases, and as the aggregate perception of corruption in their country of residence increases.

Second, we explore the interplay between corruption, income and life satisfaction. We find that that the rich experience a much lower negative effect of corruption on life satisfaction. Conversely, the poor are much more strongly affected by corruption, it decreases their life satisfaction to a greater extent. We also test whether corruption has a moderating effect on the education-well-being relationship. We find similar results to those discussed in relation to income. So overall, corruption affects more negatively the less educated and less wealthy. These findings highlight that corruption magnifies the differences in life satisfaction between the rich and the poor, and the educated versus the less educated: it contributes to creating non-monetary inequality.

Overall our findings are interesting in the light of a recent Helliwell et al. (2016), which argued for further investigation of the causes behind inequality in life satisfaction. Here we present evidence suggesting that corruption can explain differences in life satisfaction in many ways. Direct experience might not matter as much as the perceived risk of having to pay a bribe, or the perceived need of political connection-suggesting that it is the uncertainty and relative barriers imposed by corruption that matter the most, rather than simply the fact of paying a bribe. In addition, macro-level perception of corruption, and thus low institutional quality, dwarfs the direct individual costs on wellbeing. It thus suggest that no matter the small individual gains potentially associated with corrupt practices, high corruption is associated with a significantly lower aggregate wellbeing overall, especially for those less well educated or with lower income, who might have less means to shields themselves from corruption.

Our study fills a gap in the literature by exploring jointly the impact of corruption on subjective wellbeing at the individual and aggregate levels (as well as their interaction) in Central and Eastern Europe. However it also opens new questions. Firstly, why is the region different from China and Latin America, in that the direct individual cost associated with corruption does not reduce with incidence? Analysing this would require data on the specific mechanisms through which individual costs can be expected to lower, for example relating to guilt or stigmatisation. Additionally, further studies into the channels through which aggregate corruption matters for life satisfaction clarifying how wealthier and better educated respondents in particular are better able to maintain their life satisfaction in context of high corruption would also be particularly interesting. Finally, data relating to externally observed bribe paying (rather than reported bribe paying) could also be useful to confirm our interpretations on the patterns observed for the different measures of corruption used in this paper.

Acknowledgement The authors would like to thank two anonymous reviewers for their very useful feedback and suggestions. Both authors contributed equally. The usual disclaimer applies. 
Open Access This article is licensed under a Creative Commons Attribution 4.0 International License, which permits use, sharing, adaptation, distribution and reproduction in any medium or format, as long as you give appropriate credit to the original author(s) and the source, provide a link to the Creative Commons licence, and indicate if changes were made. The images or other third party material in this article are included in the article's Creative Commons licence, unless indicated otherwise in a credit line to the material. If material is not included in the article's Creative Commons licence and your intended use is not permitted by statutory regulation or exceeds the permitted use, you will need to obtain permission directly from the copyright holder. To view a copy of this licence, visit http://creativecommons.org/licenses/by/4.0/.

\section{Appendix}

See Tables 5, 6, 7, 8, 9, 10, 11, 12 and Figs. 1, 2, 3, 4, 5.

Table 5 Descriptive statistics

\begin{tabular}{|c|c|c|c|c|c|c|c|c|c|}
\hline \multirow[t]{2}{*}{ Variable } & \multicolumn{3}{|c|}{ All countries } & \multicolumn{3}{|c|}{ Not East Europe } & \multicolumn{3}{|c|}{ East Europe } \\
\hline & Obs & Mean & SD & Obs & Mean & SD & Obs & Mean & SD \\
\hline Life satisfaction & 38,207 & 3.182 & 1.088 & 6459 & 3.623 & 1.0262 & 31,748 & 3.092 & 1.078 \\
\hline Age & 38,840 & 45.884 & 17.374 & 6500 & 48.668 & 16.686 & 32,339 & 45.325 & 17.456 \\
\hline Male & 38,864 & 0.395 & 0.489 & 6501 & 0.426 & 0.494 & 32,356 & 0.389 & 0.487 \\
\hline Work & 38,857 & 0.494 & 0.499 & 6501 & 0.540 & 0.498 & 32,356 & 0.485 & 0.499 \\
\hline High income & 38,235 & 0.229 & 0.420 & 6441 & 0.333 & 0.471 & 31,787 & 0.209 & 0.406 \\
\hline Middle income & 38,235 & 0.470 & 0.499 & 6441 & 0.446 & 0.497 & 31,787 & 0.475 & 0.499 \\
\hline Low income & 38,864 & 0.294 & 0.455 & 6501 & 0.218 & 0.413 & 32,356 & 0.309 & 0.462 \\
\hline Religious & 38,856 & 0.187 & 0.390 & 6501 & 0.241 & 0.427 & 32,355 & 0.176 & 0.381 \\
\hline Poor health & 38,681 & 0.128 & 0.334 & 6492 & 0.074 & 0.263 & 32,189 & 0.139 & 0.346 \\
\hline Married & 38,630 & 0.592 & 0.491 & 6490 & 0.544 & 0.498 & 32,140 & 0.601 & 0.489 \\
\hline Higher education & 38,847 & 0.372 & 0.483 & 6500 & 0.345 & 0.475 & 32,347 & 0.377 & 0.484 \\
\hline Secondary education & 38,847 & 0.319 & 0.466 & 6500 & 0.261 & 0.439 & 32,347 & 0.330 & 0.470 \\
\hline Low education & 38,864 & 0.308 & 0.461 & 6501 & 0.393 & 0.488 & 32,356 & 0.291 & 0.454 \\
\hline Father education & 29,390 & 9.197 & 4.268 & 5331 & 8.462 & 4.342 & 24,052 & 9.363 & 4.232 \\
\hline Local admin & 35,744 & 3.078 & 0.953 & 6254 & 3.246 & 0.922 & 29,490 & 3.0425 & 0.956 \\
\hline National admin & 34,053 & 2.842 & 0.994 & 6187 & 2.876 & 0.991 & 27,866 & 2.835 & 0.995 \\
\hline Political connections & 36,333 & 0.261 & 0.439 & 6224 & 0.139 & 0.346 & 30,109 & 0.287 & 0.452 \\
\hline Perceived corruption & 31,827 & 5.416 & 7.262 & 6050 & 2.244 & 4.950 & 25,777 & 6.160 & 7.513 \\
\hline Control of corruption & 38,858 & -0.102 & 0.864 & 6501 & 1.187 & 0.838 & 32,356 & -0.361 & 0.595 \\
\hline Governance indicator & 38,858 & 0.105 & 0.781 & 6501 & 1.067 & 0.598 & 32,356 & -0.087 & 0.662 \\
\hline Victimisation & 37,592 & 0.320 & 0.759 & 6488 & 0.053 & 0.292 & 31,104 & 0.376 & 0.813 \\
\hline
\end{tabular}

The variables in the table are defined as follow: life satisfaction is the life satisfaction indicator on 1-5 scale; age is the individual age in year; work is dummy variable for work status; high income and middle income are dummy variables for income level; poor health is a dummy variable for health problems; married is a dummy variable for marital status; higher education and secondary education are dummies variable for education level; father education is a dummy variable taking one if the father has a high education level; local admin and national administration are dummies variable taking value one if the individual is satisfied with the local and national administration; Political connection is a dummy variable taking value one if political connection is considered more important then merit; control of corruption is the corruption indicator form the World Bank Governance dataset; governance index is aggregate World Bank Governance indicator; perceived corruption is the average of how likely it is that bribery will be paid by "someone like me" when trying the access a public service; victimisation is a variable which sums scores measuring how often it is that 'unofficial payment' will be paid by "someone like me" 
Table 6 Corruption level by country

\begin{tabular}{|c|c|c|c|c|c|}
\hline Country & $\begin{array}{l}\text { Governance } \\
\text { indicator }\end{array}$ & $\begin{array}{l}\text { Control of cor- } \\
\text { ruption }\end{array}$ & $\begin{array}{l}\text { Political Con- } \\
\text { nection }\end{array}$ & Victimisation & $\begin{array}{l}\text { Perceived } \\
\text { corruption }\end{array}$ \\
\hline \multicolumn{6}{|c|}{ Transition countries } \\
\hline Albania & -0.174 & -0.489 & 0.310 & 0.920 & 9.091 \\
\hline Armenia & -0.301 & -0.651 & 0.340 & 0.168 & 8.982 \\
\hline Azerbaijan & -0.784 & -1.179 & 0.128 & 1.381 & 21.849 \\
\hline Belarus & -0.955 & -0.730 & 0.192 & 0.341 & 5.080 \\
\hline Bosnia & -0.389 & -0.325 & 0.393 & 0.168 & 5.941 \\
\hline Bulgaria & 0.215 & -0.207 & 0.403 & 0.173 & 4.162 \\
\hline Croatia & 0.389 & -0.029 & 0.533 & 0.054 & 4.351 \\
\hline Czech Republic & 0.894 & 0.259 & 0.306 & 0.175 & 5.880 \\
\hline Estonia & 1.032 & 0.861 & 0.211 & 0.120 & 0.985 \\
\hline Georgia & -0.059 & -0.119 & 0.166 & 0.040 & 2.720 \\
\hline Hungary & 0.709 & 0.252 & 0.333 & 0.186 & 5.774 \\
\hline Kazakhstan & -0.500 & -0.975 & 0.212 & 0.438 & 5.457 \\
\hline Kyrgyzstan & -0.879 & -1.109 & 0.121 & 1.265 & 14.435 \\
\hline Latvia & 0.644 & 0.125 & 0.244 & 0.183 & 2.091 \\
\hline Lithuania & 0.720 & 0.271 & 0.316 & 0.421 & 3.571 \\
\hline Macedonia & -0.102 & -0.057 & 0.561 & 0.169 & 4.115 \\
\hline Moldova & -0.386 & -0.686 & 0.125 & 0.468 & 10.001 \\
\hline Mongolia & -0.213 & -0.730 & 0.124 & 0.256 & 6.561 \\
\hline Poland & 0.785 & 0.413 & 0.210 & 0.088 & 2.769 \\
\hline Romania & 0.146 & -0.215 & 0.289 & 0.355 & 7.199 \\
\hline Russia & -0.739 & -1.059 & 0.264 & 0.363 & 4.543 \\
\hline Serbia & -0.154 & -0.287 & 0.534 & 0.192 & 4.373 \\
\hline Slovakia & 0.751 & 0.235 & 0.376 & 0.201 & 7.938 \\
\hline Slovenia & 0.915 & 0.854 & 0.387 & 0.059 & 3.505 \\
\hline Tajikistan & -1.110 & -1.198 & 0.078 & 0.778 & 9.305 \\
\hline Ukraine & -0.529 & -0.975 & 0.303 & 0.717 & 8.480 \\
\hline Uzbekistan & -1.288 & -1.243 & 0.082 & 0.788 & 5.424 \\
\hline Kosovo & -0.544 & -0.624 & 0.406 & 0.116 & 4.207 \\
\hline Montenegro & 0.088 & -0.238 & 0.336 & 0.247 & 5.159 \\
\hline \multicolumn{6}{|c|}{ Non-East European countries } \\
\hline France & 1.263 & 1.436 & 0.136 & 0.031 & 1.894 \\
\hline Germany & 1.432 & 1.737 & 0.101 & 0.098 & 1.503 \\
\hline Great Britain & 1.386 & 1.560 & 0.059 & 0.048 & 0.827 \\
\hline Italy & 0.523 & -0.005 & 0.285 & 0.018 & 2.459 \\
\hline Sweden & 1.771 & 2.319 & 0.044 & 0.010 & 0.234 \\
\hline Turkey & -0.046 & 0.030 & 0.230 & 0.112 & 7.758 \\
\hline
\end{tabular}




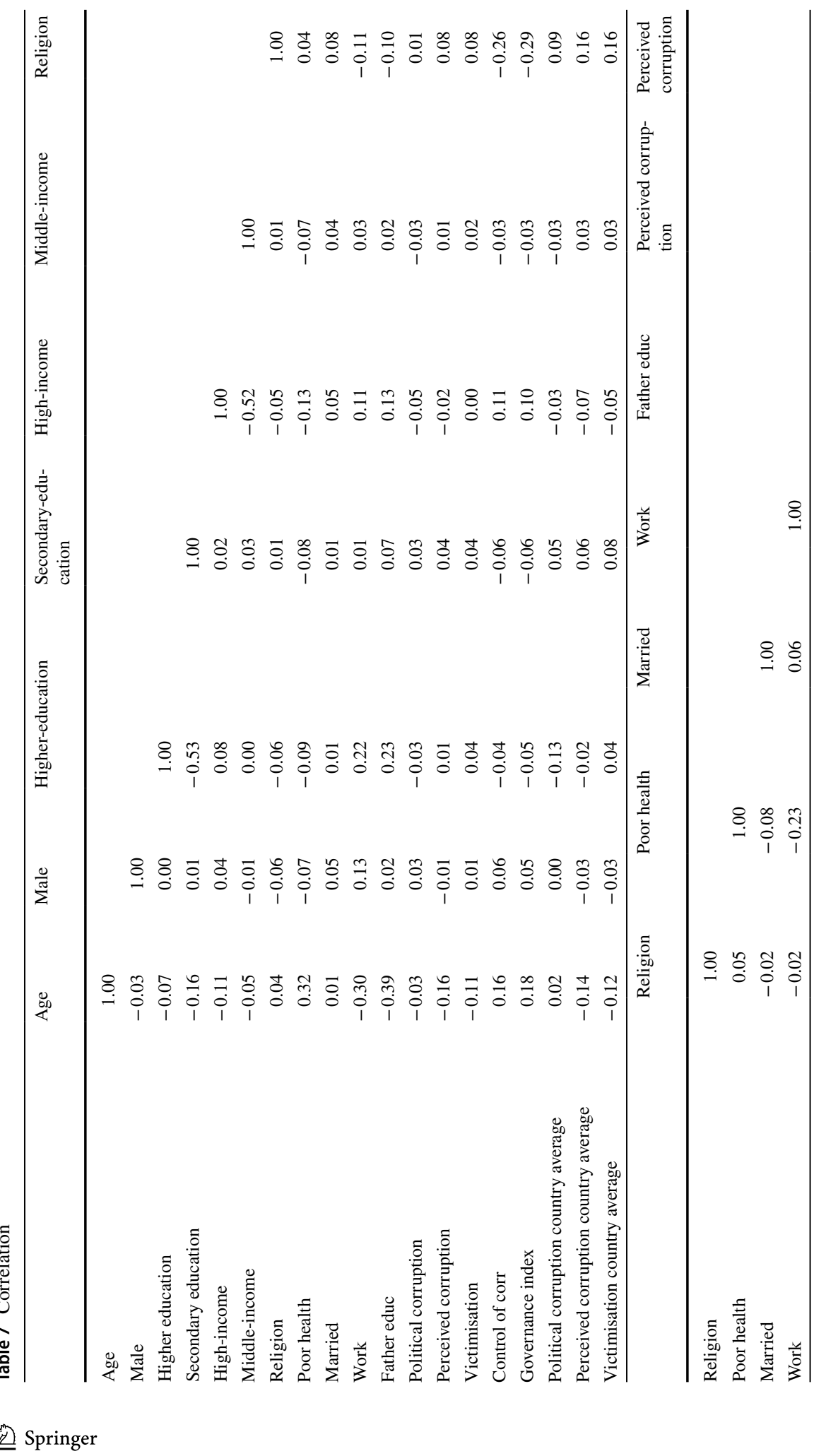




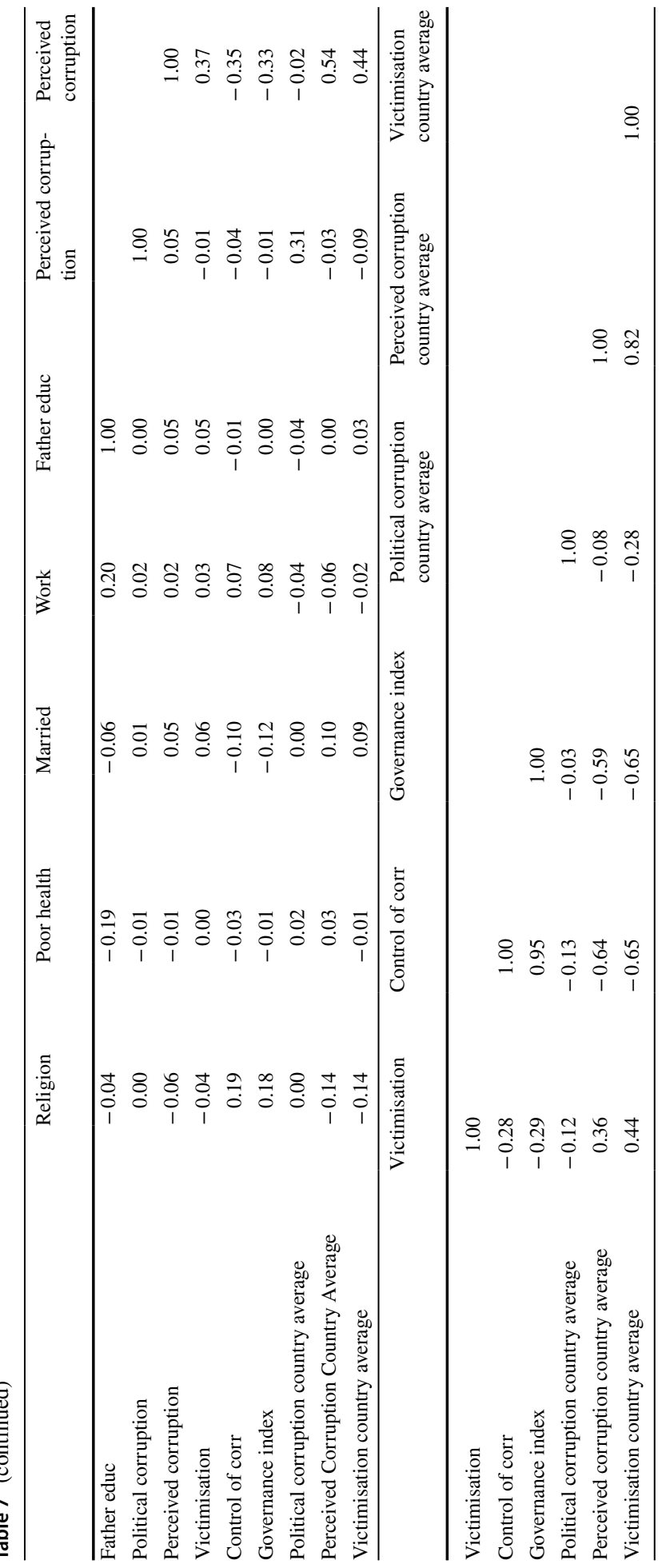


Table 8 Random slopes

\begin{tabular}{|c|c|c|c|}
\hline \multirow[t]{2}{*}{ Variables } & \multicolumn{3}{|c|}{ Life satisfaction } \\
\hline & (1) & (6) & $(11)$ \\
\hline \multicolumn{4}{|c|}{ Individual level variables } \\
\hline Age & $\begin{array}{l}-0.0312 * * * \\
(0.002)\end{array}$ & $\begin{array}{l}-0.030 * * * \\
(0.002)\end{array}$ & $\begin{array}{l}-0.031 \text { *** } \\
(0.002)\end{array}$ \\
\hline Age squared & $\begin{array}{l}0.000 * * * \\
(2.22 \mathrm{e}-05)\end{array}$ & $\begin{array}{l}0.000 * * * \\
(2.41 \mathrm{e}-05)\end{array}$ & $\begin{array}{l}0.000 * * * \\
(2.25 \mathrm{e}-05)\end{array}$ \\
\hline Male & $\begin{array}{l}-0.031 * * * \\
(0.012)\end{array}$ & $\begin{array}{l}-0.033 * * \\
(0.013)\end{array}$ & $\begin{array}{l}-0.025^{* * *} \\
(0.012)\end{array}$ \\
\hline Work & $\begin{array}{l}0.059 * * * \\
(0.013)\end{array}$ & $\begin{array}{l}0.056^{* * * *} \\
(0.014)\end{array}$ & $\begin{array}{l}0.059 * * * \\
(0.013)\end{array}$ \\
\hline High income & $\begin{array}{l}0.791 * * * \\
(0.017)\end{array}$ & $\begin{array}{l}0.786^{* * * *} \\
(0.019)\end{array}$ & $\begin{array}{l}0.793 * * * \\
(0.018)\end{array}$ \\
\hline Middle income & $\begin{array}{l}0.511 * * * \\
(0.014)\end{array}$ & $\begin{array}{l}0.505^{* * * *} \\
(0.015)\end{array}$ & $\begin{array}{l}0.514 * * * \\
(0.014)\end{array}$ \\
\hline Religion & $\begin{array}{l}0.021 \\
(0.015)\end{array}$ & $\begin{array}{l}0.021 \\
(0.017)\end{array}$ & $\begin{array}{l}0.023 \\
(0.016)\end{array}$ \\
\hline Poor health & $\begin{array}{l}-0.280^{* * * *} \\
(0.020)\end{array}$ & $\begin{array}{l}-0.253^{* * *} \\
(0.022)\end{array}$ & $\begin{array}{l}-0.276^{* * * *} \\
(0.020)\end{array}$ \\
\hline Married & $\begin{array}{l}0.121 * * * \\
(0.013)\end{array}$ & $\begin{array}{l}0.131 * * * \\
(0.014)\end{array}$ & $\begin{array}{l}0.118 * * * \\
(0.013)\end{array}$ \\
\hline Higher education & $\begin{array}{l}0.145 * * * \\
(0.017)\end{array}$ & $\begin{array}{l}0.138 * * * \\
(0.018)\end{array}$ & $\begin{array}{l}0.145^{* * *} \\
(0.017)\end{array}$ \\
\hline Secondary education & $\begin{array}{l}0.054 * * * \\
(0.016)\end{array}$ & $\begin{array}{l}0.0544 * * * \\
(0.017)\end{array}$ & $\begin{array}{l}0.0503 * * * \\
(0.016)\end{array}$ \\
\hline Father education & $\begin{array}{l}0.004 * * \\
(0.001)\end{array}$ & $\begin{array}{l}0.004 * * \\
(0.001)\end{array}$ & $\begin{array}{l}0.004 * * \\
(0.001)\end{array}$ \\
\hline Local admin & $\begin{array}{l}0.073 * * * \\
(0.007)\end{array}$ & $\begin{array}{l}0.065^{* * *} \\
(0.008)\end{array}$ & $\begin{array}{l}0.070 * * * \\
(0.008)\end{array}$ \\
\hline National admin & $\begin{array}{l}0.139 * * * \\
(0.008)\end{array}$ & $\begin{array}{l}0.136^{* * * *} \\
(0.008)\end{array}$ & $\begin{array}{l}0.137 * * * \\
(0.008)\end{array}$ \\
\hline \multicolumn{4}{|l|}{ Country level variables } \\
\hline Political connection & $\begin{array}{l}-0.886 \\
(0.112)\end{array}$ & & \\
\hline Perceived corruption & & $\begin{array}{l}-0.003 \\
(0.002)\end{array}$ & \\
\hline Victimisation & & & $\begin{array}{l}-0.025 \\
(0.015)\end{array}$ \\
\hline Constant & $\begin{array}{l}2.681 * * * \\
(0.073)\end{array}$ & $\begin{array}{l}2.636 * * * \\
(0.079)\end{array}$ & $\begin{array}{l}2.630 * * * \\
(0.075)\end{array}$ \\
\hline \multicolumn{4}{|l|}{ Random effects } \\
\hline Var (political con) & $\begin{array}{l}8.67 e-09 \\
\text { (.) }\end{array}$ & & \\
\hline Var (perceived corr) & & $\begin{array}{l}0.000 \\
(0.000)\end{array}$ & \\
\hline Var (victimisation) & & & .004 \\
\hline
\end{tabular}


Table 8 (continued)

\begin{tabular}{llll}
\hline Variables & \multicolumn{2}{l}{ Life satisfaction } & \\
\cline { 2 - 4 } & $(1)$ & $(6)$ & $(11)$ \\
\hline & & & $(.001)$ \\
Observations & 24,169 & 24,439 & 24,439 \\
Number of groups & 35 & 35 & 35 \\
\hline
\end{tabular}

Standard errors in parentheses; age is the individual age in year; work is dummy variable for work status; high income and middle-income are dummy variables for income level; poor health is a dummy variable for health problems; married is a dummy variable for marital status; higher education and secondary education are dummies variable for education level; father education is a dummy variable taking one if the father has a high education level; local admin and national administration are dummies variable taking value one if the individual is satisfied with the local and national administration; Political connection is a dummy variable taking value one if political connection is considered more important than merit; perceived corruption is the average of how likely it is that bribery will be paid by "someone like me" when trying the access a public service; victimisation is a variable which sums scores measuring how often it is that 'unofficial payment' will be paid by "someone like me"

$* * * p<0.01 ; * * p<0.05 ; * p<0.1$ 


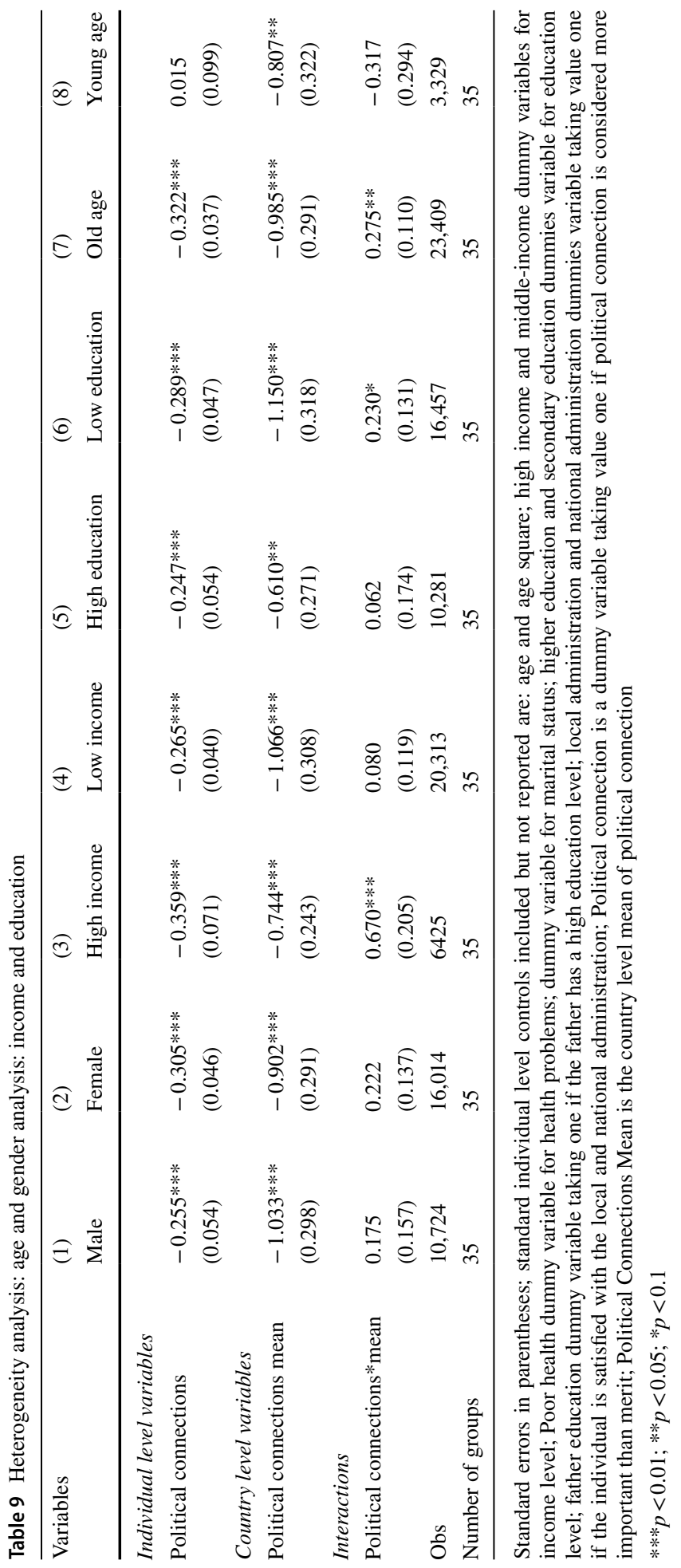




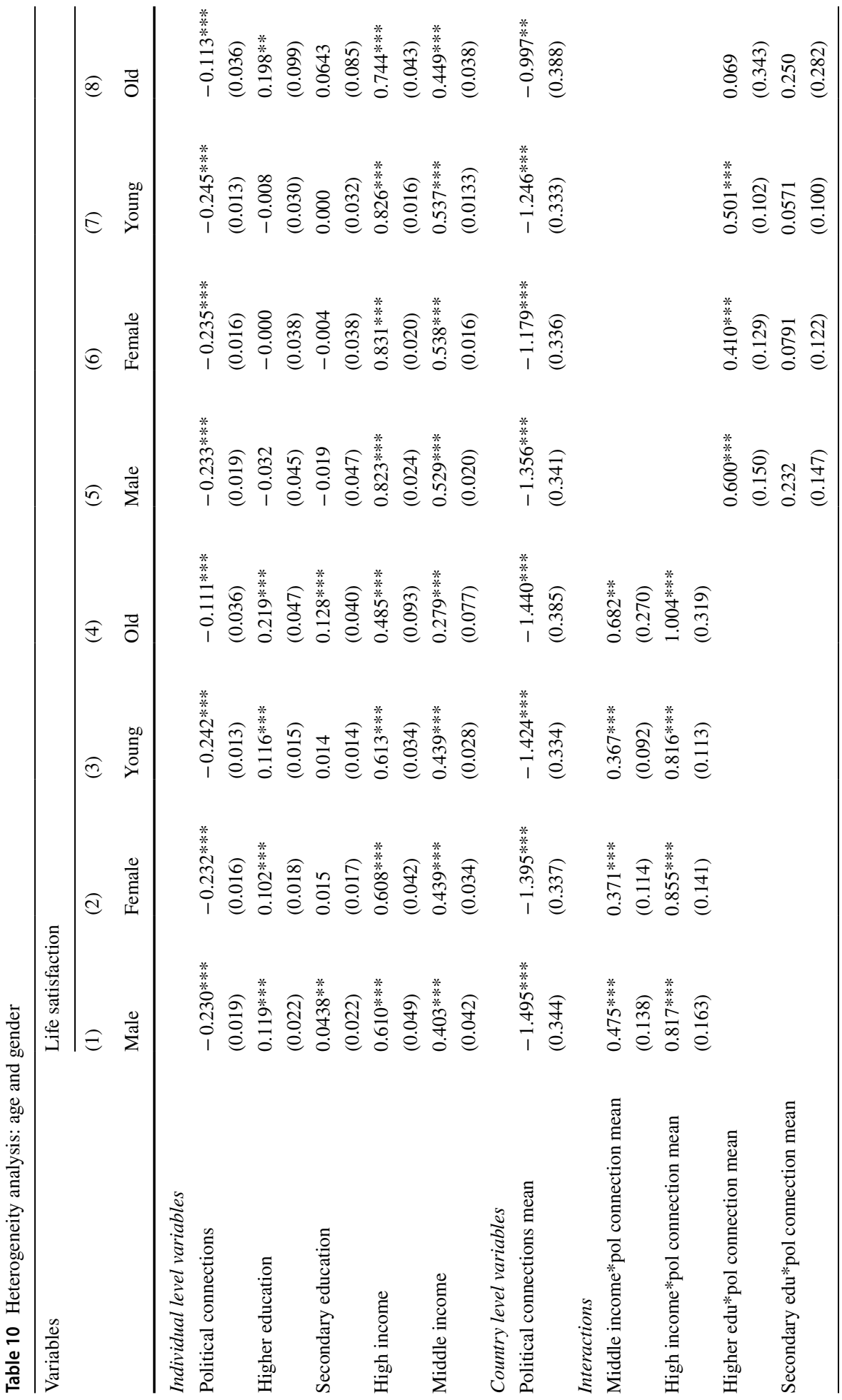




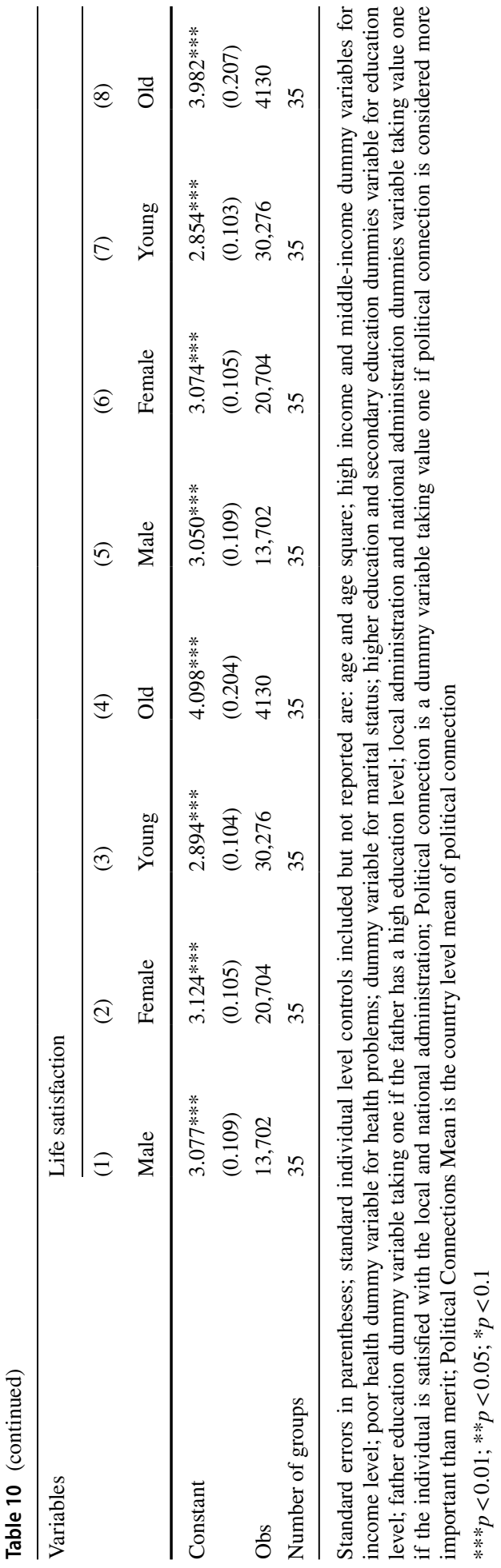


Table 11 Potential aggregate confounding factors

\begin{tabular}{|c|c|c|c|c|c|c|}
\hline \multirow[t]{2}{*}{ Variables } & \multicolumn{6}{|c|}{ Life satisfaction } \\
\hline & (1) & (2) & (3) & (4) & (5) & (6) \\
\hline \multicolumn{7}{|c|}{ Individual level variables } \\
\hline Age & $\begin{array}{l}-0.030^{* * *} \\
(0.002)\end{array}$ & $\begin{array}{l}-0.030^{* * *} \\
(0.002)\end{array}$ & $\begin{array}{l}-0.030 * * * \\
(0.002)\end{array}$ & $\begin{array}{l}-0.030^{* * *} \\
(0.002)\end{array}$ & $\begin{array}{l}-0.030 * * * \\
(0.002)\end{array}$ & $\begin{array}{l}-0.030^{* * *} \\
(0.002)\end{array}$ \\
\hline Age squared & $\begin{array}{l}0.000 * * * \\
(2.41 \mathrm{e}-05)\end{array}$ & $\begin{array}{l}0.000 * * * \\
(2.41 \mathrm{e}-05)\end{array}$ & $\begin{array}{l}0.000 * * * \\
(2.41 \mathrm{e}-05)\end{array}$ & $\begin{array}{l}0.000 * * * \\
(2.41 \mathrm{e}-05)\end{array}$ & $\begin{array}{l}0.000 * * * \\
(2.41 \mathrm{e}-05)\end{array}$ & $\begin{array}{l}0.000 * * * \\
(2.41 \mathrm{e}-05)\end{array}$ \\
\hline Male & $\begin{array}{l}-0.029 * * \\
(0.013)\end{array}$ & $\begin{array}{l}-0.029 * * \\
(0.013)\end{array}$ & $\begin{array}{l}-0.029 * * \\
(0.013)\end{array}$ & $\begin{array}{l}-0.029 * * \\
(0.013)\end{array}$ & $\begin{array}{l}-0.029 * * \\
(0.013)\end{array}$ & $\begin{array}{l}-0.029 * * \\
(0.013)\end{array}$ \\
\hline Work & $\begin{array}{l}0.059 * * * \\
(0.015)\end{array}$ & $\begin{array}{l}0.059 * * * \\
(0.015)\end{array}$ & $\begin{array}{l}0.059 * * * \\
(0.015)\end{array}$ & $\begin{array}{l}0.059 * * * \\
(0.015)\end{array}$ & $\begin{array}{l}0.059 * * * \\
(0.015)\end{array}$ & $\begin{array}{l}0.059 * * * \\
(0.015)\end{array}$ \\
\hline High income & $\begin{array}{l}0.802 * * * \\
(0.019)\end{array}$ & $\begin{array}{l}0.801 * * * \\
(0.019)\end{array}$ & $\begin{array}{l}0.802 * * * \\
(0.019)\end{array}$ & $\begin{array}{l}0.802 * * * \\
(0.019)\end{array}$ & $\begin{array}{l}0.802 * * * \\
(0.019)\end{array}$ & $\begin{array}{l}0.801 \text { *** } \\
(0.019)\end{array}$ \\
\hline Middle income & $\begin{array}{l}0.517 * * * \\
(0.015)\end{array}$ & $\begin{array}{l}0.517 * * * \\
(0.015)\end{array}$ & $\begin{array}{l}0.517 * * * \\
(0.015)\end{array}$ & $\begin{array}{l}0.517 * * * \\
(0.015)\end{array}$ & $\begin{array}{l}0.517 * * * \\
(0.015)\end{array}$ & $\begin{array}{l}0.517 * * * \\
(0.015)\end{array}$ \\
\hline Religious & $\begin{array}{l}0.023 \\
(0.0171)\end{array}$ & $\begin{array}{l}0.023 \\
(0.017)\end{array}$ & $\begin{array}{l}0.022 \\
(0.017)\end{array}$ & $\begin{array}{l}0.022 \\
(0.017)\end{array}$ & $\begin{array}{l}0.023 \\
(0.017)\end{array}$ & $\begin{array}{l}0.023 \\
(0.017)\end{array}$ \\
\hline Poor health & $\begin{array}{l}-0.281 * * * \\
(0.022)\end{array}$ & $\begin{array}{l}-0.281 * * * \\
(0.022)\end{array}$ & $\begin{array}{l}-0.282^{* * * *} \\
(0.022)\end{array}$ & $\begin{array}{l}-0.281 * * * \\
(0.022)\end{array}$ & $\begin{array}{l}-0.281 * * * \\
(0.022)\end{array}$ & $\begin{array}{l}-0.281 * * * \\
(0.022)\end{array}$ \\
\hline Married & $\begin{array}{l}0.123 * * * \\
(0.014)\end{array}$ & $\begin{array}{l}0.123 * * * \\
(0.014)\end{array}$ & $\begin{array}{l}0.123 * * * \\
(0.014)\end{array}$ & $\begin{array}{l}0.123 * * * \\
(0.014)\end{array}$ & $\begin{array}{l}0.123 * * * \\
(0.014)\end{array}$ & $\begin{array}{l}0.123 * * * \\
(0.014)\end{array}$ \\
\hline Higher education & $\begin{array}{l}0.130 * * * \\
(0.018)\end{array}$ & $\begin{array}{l}0.130 * * * \\
(0.018)\end{array}$ & $\begin{array}{l}0.130 * * * \\
(0.018)\end{array}$ & $\begin{array}{l}0.130 * * * \\
(0.018)\end{array}$ & $\begin{array}{l}0.130 * * * \\
(0.018)\end{array}$ & $\begin{array}{l}0.130 * * * \\
(0.018)\end{array}$ \\
\hline Secondary education & $\begin{array}{l}0.0323 * \\
(0.017)\end{array}$ & $\begin{array}{l}0.032 * \\
(0.017)\end{array}$ & $\begin{array}{l}0.032 * \\
(0.017)\end{array}$ & $\begin{array}{l}0.032 * \\
(0.017)\end{array}$ & $\begin{array}{l}0.032 * \\
(0.017)\end{array}$ & $\begin{array}{l}0.0327 * \\
(0.017)\end{array}$ \\
\hline Father education & $\begin{array}{l}0.004 * * \\
(0.001)\end{array}$ & $\begin{array}{l}0.00440 * * \\
(0.001)\end{array}$ & $\begin{array}{l}0.004 * * \\
(0.001)\end{array}$ & $\begin{array}{l}0.004 * * \\
(0.001)\end{array}$ & $\begin{array}{l}0.004 * * \\
(0.0018)\end{array}$ & $\begin{array}{l}0.004 * * \\
(0.001)\end{array}$ \\
\hline Local administration & $\begin{array}{l}0.065^{* * * *} \\
(0.0085)\end{array}$ & $\begin{array}{l}0.065^{* * * *} \\
(0.008)\end{array}$ & $\begin{array}{l}0.065^{* * * *} \\
(0.008)\end{array}$ & $\begin{array}{l}0.065^{* * * *} \\
(0.008)\end{array}$ & $\begin{array}{l}0.065^{* * * *} \\
(0.008)\end{array}$ & $\begin{array}{l}0.0657 * * * \\
(0.008)\end{array}$ \\
\hline National admin & $\begin{array}{l}0.132 * * * \\
(0.008)\end{array}$ & $\begin{array}{l}0.132 * * * \\
(0.008)\end{array}$ & $\begin{array}{l}0.132 * * * \\
(0.008)\end{array}$ & $\begin{array}{l}0.132 * * * \\
(0.008)\end{array}$ & $\begin{array}{l}0.132 * * * \\
(0.008)\end{array}$ & $\begin{array}{l}0.132 * * * \\
(0.008)\end{array}$ \\
\hline \multicolumn{7}{|l|}{ Country level variables } \\
\hline Gini & $\begin{array}{l}-0.012 \\
(0.011)\end{array}$ & $\begin{array}{l}-0.015 \\
(0.010)\end{array}$ & $\begin{array}{l}-0.015 \\
(0.010)\end{array}$ & $\begin{array}{l}-0.014 \\
(0.010)\end{array}$ & $\begin{array}{l}-0.011 \\
(0.011)\end{array}$ & $\begin{array}{l}-0.015 \\
(0.010)\end{array}$ \\
\hline Log GDP per capita & $\begin{array}{l}0.117 * * * \\
(0.042)\end{array}$ & $\begin{array}{l}0.019 \\
(0.048)\end{array}$ & $\begin{array}{l}-0.004 \\
(0.069)\end{array}$ & $\begin{array}{l}-0.026 \\
(0.064)\end{array}$ & $\begin{array}{l}0.081 \\
(0.084)\end{array}$ & $\begin{array}{l}0.020 \\
(0.076)\end{array}$ \\
\hline West Europe & & $\begin{array}{l}0.454 * * * \\
(0.148)\end{array}$ & & $\begin{array}{l}0.380 * * \\
(0.161)\end{array}$ & & $\begin{array}{l}0.454 * * * \\
(0.150)\end{array}$ \\
\hline Control of corruption & & & $\begin{array}{l}0.192 * * \\
(0.090)\end{array}$ & $\begin{array}{l}0.097 \\
(0.092)\end{array}$ & & \\
\hline Governance index & & & & & $\begin{array}{l}0.062 \\
(0.127)\end{array}$ & $\begin{array}{l}-0.003 \\
(0.113)\end{array}$ \\
\hline Constant & $\begin{array}{l}1.963 * * * \\
(0.568)\end{array}$ & $\begin{array}{l}2.874 * * * \\
(0.580)\end{array}$ & $\begin{array}{l}3.043 * * * \\
(0.735)\end{array}$ & $\begin{array}{l}3.273 * * * \\
(0.684)\end{array}$ & $\begin{array}{l}2.247 * * * \\
(0.809)\end{array}$ & $\begin{array}{l}2.861 * * * \\
(0.741)\end{array}$ \\
\hline Observations & 21,582 & 21,582 & 21,582 & 21,582 & 21,582 & 21,582 \\
\hline
\end{tabular}


Table 11 (continued)

\begin{tabular}{lllllll}
\hline Variables & \multicolumn{4}{l}{ Life satisfaction } & & \\
\cline { 2 - 7 } & $(1)$ & $(2)$ & $(3)$ & $(4)$ & $(5)$ & $(6)$ \\
\hline Number of groups & 31 & 31 & 31 & 31 & 31 & 31
\end{tabular}

Standard errors in parentheses; age is the individual age in year; work is dummy variable for work status; high income and middle income are dummy variables for income level; poor health is a dummy variable for health problems; married is a dummy variable for marital status; Higher education and secondary education are dummies variable for education level; father education is a dummy variable taking one if the father has a high education level; local admin and national administration are dummies variable taking value one if the individual is satisfied with the local and national administration; control of corruption is the corruption indicator form the World Bank Governance dataset; Governance Index Is Aggregate World Bank Governance indicator

$* * * p<0.01 ; * * p<0.05 ; * p<0.1$ 
Table 12 Potential confounding factors

\begin{tabular}{|c|c|c|c|c|}
\hline \multirow[t]{2}{*}{ Variables } & \multicolumn{4}{|c|}{ Life satisfaction } \\
\hline & (1) & (2) & (3) & (4) \\
\hline \multicolumn{5}{|l|}{ Individual level variables } \\
\hline Political connections & $\begin{array}{l}-0.285^{* * *} \\
(0.045)\end{array}$ & $\begin{array}{l}-0.305^{* * *} \\
(0.040)\end{array}$ & & \\
\hline Perceived corruption & $\begin{array}{l}-0.012 * * * \\
(0.002)\end{array}$ & & $\begin{array}{l}-0.0134 * * * \\
(0.002)\end{array}$ & \\
\hline Victimisation & $\begin{array}{l}0.008 \\
(0.020)\end{array}$ & & & $\begin{array}{l}-0.026 \\
(0.017)\end{array}$ \\
\hline \multicolumn{5}{|l|}{ Country level variables } \\
\hline Gini & $\begin{array}{l}-0.018 * \\
(0.010)\end{array}$ & $\begin{array}{l}-0.012 \\
(0.010)\end{array}$ & $\begin{array}{l}-0.021 * \\
(0.012)\end{array}$ & $\begin{array}{l}-0.011 \\
(0.013)\end{array}$ \\
\hline Log GDP per capita & $\begin{array}{l}0.037 \\
(0.058)\end{array}$ & $\begin{array}{l}0.111 * * * \\
(0.037)\end{array}$ & $\begin{array}{l}0.022 \\
(0.068)\end{array}$ & $\begin{array}{l}0.125^{*} \\
(0.065)\end{array}$ \\
\hline Political connections mean & $\begin{array}{l}-0.987 * * * \\
(0.315)\end{array}$ & $\begin{array}{l}-1.087^{* * * *} \\
(0.322)\end{array}$ & & \\
\hline Perceived corruption mean & $\begin{array}{l}-0.039 \\
(0.024)\end{array}$ & & $\begin{array}{l}-0.043 * \\
(0.024)\end{array}$ & \\
\hline Victimisation mean & $\begin{array}{l}0.0142 \\
(0.234)\end{array}$ & & & $\begin{array}{l}0.104 \\
(0.259)\end{array}$ \\
\hline \multicolumn{5}{|l|}{ Interaction terms } \\
\hline Political connections*mean & $\begin{array}{l}0.236^{*} \\
(0.134)\end{array}$ & $\begin{array}{l}0.251 * * \\
(0.122)\end{array}$ & & \\
\hline Perceived corruption*mean & $\begin{array}{l}0.0014 * * * \\
(0.000)\end{array}$ & & $\begin{array}{l}0.001 * * * \\
(0.000)\end{array}$ & \\
\hline Victimisation*mean & $\begin{array}{l}-0.021 \\
(0.028)\end{array}$ & & & $\begin{array}{l}0.020 \\
(0.024)\end{array}$ \\
\hline Constant & $\begin{array}{l}3.413 * * * \\
(0.829)\end{array}$ & $\begin{array}{l}2.379 * * * \\
(0.506)\end{array}$ & $\begin{array}{l}3.306^{* * *} \\
(0.974)\end{array}$ & $\begin{array}{l}1.797 * * \\
(0.903)\end{array}$ \\
\hline Observations & 18,899 & 22,826 & 20,424 & 23,321 \\
\hline Number of groups & 31 & 31 & 31 & 31 \\
\hline
\end{tabular}

Standard errors in parentheses; standard individual level controls included but not reported are: age and age square; high income and middle-income dummy variables for income level; poor health dummy variable for health problems; dummy variable for marital status; higher education and secondary education dummies variable for education level; father education dummy variable taking one if the father has a high education level; local administration and national administration dummies variable taking value one if the individual is satisfied with the local and national administration; political connection is a dummy variable taking value one if political connection is considered more important than merit; political connection is a dummy variable taking value one if political connection is considered more important than merit; perceived corruption is the average of how likely it is that bribery will be paid by "someone like me" when trying the access a public service; victimisation is a variable which sums scores measuring how often it is that 'unofficial payment' will be paid by "someone like me". The interactions term are: political connections, perceived corruption and victimisation at individual level multiplied their respective country level average

$* * * p<0.01 ; * * p<0.05 ; * p<0.1$ 


\section{References}

Ammermueller, A. (2007). PISA: What makes the difference? Explaining the gap in test scores between Finland and Germany. Empirical Economics, 33(2), 263-287.

Anderson, R. (2009). Second European quality of life survey: Overview, office for official publications of the European communities.

Arvin, M., \& Lew, B. (2014). Does income matter in the happiness-corruption relationship? Journal of Economic Studies, 41(3), 469-490.

Birdsall, N., \& Londono, J. L. (1997). Asset inequality matters: An assessment of the world bank's approach to poverty reduction. American Economic Review, Papers and Proceedings, 87(2), 32-37.

Blanchflower, D., \& Oswald, A. (2008). Is well-being U-shaped over the life cycle? Social Science and Medicine, 66(8), 1733-1749.

Campante, F., \& Chor, D. (2012). Why was the arab world poised for revolution? Schooling, economic opportunities, and the Arab Spring. Journal of Economic Prospective, 26(2), 167-188.

Cialdini, R., \& Trost, M. (1998). Social influence: Social norms, conformity and compliance. In D. T. Gilbert, S. T. Fiske, \& L. Lindzey (Eds.), The handbook of social psychology (pp. 151-192). New York: McGraw-Hill.

Clark, A. E. (2003). Unemployment as a social norm: Psychological evidence from panel data. Journal of Labor Economics, 21(2), 323-351.

Clark, A., \& Oswald, A. (1994). Unhappiness and unemployment. The Economic Journal, 104(424), 648-659.

Cojocaru, A. (2014). Fairness and inequality tolerance: Evidence from the LITS. Journal of Comparative Economics., 42(3), 590-608.

Coleman, J. (1990). Foundations of social theory. Cambridge, MA: Harvard University Press.

Di Tella, R., Galiani, S., \& Schargrodsky, E. (2010). Crime distribution and victim behavior during a crime wave. In R. Di Tella, S. Edwards, \& E. Schargrodsky (Eds.), The economics of crime: Lessons for and from Latin America. Chicago: University of Chicago Press.

Di Tella, R., MacCulloch, R., \& Oswald, A. (2003). The macroeconomics of happiness. The Review of Economics and Statistics, 85(4), 809-827.

Diener, E., Oishi, S., \& Lucas, R. E. (2003). Personality, culture, and subjective well-being: Emotional and cognitive evaluations of life. Annual Review of Psychology, 54(1), 403-425.

Djankov, S., Nikolova, E., \& Zilinsky, J. (2016). The happiness gap in Eastern Europe. Journal of Comparative Economics, 44(1), 108-124.

Dolan, P., Peasgood, T., \& White, M. (2008). Do we really know what makes us happy? A review of the economic literature on the factors associated with subjective well-being. Journal of Economic Psychology, 29, 94-122.

Douarin, E., \& Mickiewicz, T. (2017). Economics of institutional change: Central and Eastern Europe revisited. In Studies in economics transition. Basingstoke: Palgrave Macmillan.

Easterlin, A. (2009). Lost in transition: Life satisfaction on the road to capitalism. Journal of Economic Behavior and Organization, 71(2), 130-145.

Easterlin, R. A., Morgan, R., Switek, M., \& Wang, F. (2012). China's life satisfaction, 1990-2010. Proceedings of the National Academy of Sciences, 109(25), 9775-9780.

EBRD. (2017). Transition report 2016/17: Chapter 2. The impact of transition on wellbeing.

Ferrer-I-Carbonell, A., \& Frijters, P. (2004). How important is methodology for the estimates of the determinants of happiness? Economic Journal, 114(497), 641-659.

Festinger, L. (1954). A theory of social comparison processes. Human Relations, 7(2), 117-140.

Fidrmuc, J., \& Gërxhani, K. (2008). Mind the gap! Social capital, East and West. Journal of Comparative Economics, 36, 264-286.

Frey, B. S., \& Stutzer, A. (2000). Happiness, economy and institutions. Economic Journal, 110, 918-938.

Frijters, P., \& Beatton, T. (2008). The mystery of the U-shaped relationship between happiness and age. NCER working paper 26.

Graham, C. (2011). Adaptation amidst prosperity and adversity: Insights from happiness studies from around the World. The World Bank Research Observer, 26, 105-137.

Graham, C., \& Chattopadhyay, S. (2009). Well being and public attitudes in Afghanistan: Some insights from the economics of happiness. World Economics Journal, 10(3), July-September.

Guriev, S., \& Melnikov, N. (2017). Happiness convergence in transition countries. EBRD working paper no. 204

Guriev, S., \& Zhuravskaya, E. (2009). (Un)happiness in transition. The Journal of Economic Perspectives, 23(2), 143-168. 
Helliwell, J. (2003). How's life? Combining individual and national variables to explain subjective wellbeing. Economic Modelling, 20, 331-360.

Helliwell, J., \& Huang, H. F. (2008). How's your government? International evidence linking good government and well-being. British Journal of Political Science, 38, 595-619.

Helliwell, J., Layard, R., \& Sachs, J. (2016). World Happiness Report 2016, Update (Vol. I). New York: Sustainable Development Solutions Network.

Heywood, P., \& Rose, J. (2014). "Close but no Cigar": The measurement of corruption. Journal of Public Policy, 34(3), 507-529.

Kahneman, D., \& Deaton, A. (2010). High income improves evaluation of life but not emotional wellbeing. Proceedings of the National Academy of Sciences, 107(38), 16489-16493.

Kelling, G., \& Wilson, J. (1982). Broken windows: The police and neighbourhood safety. The Atlantic, 249(3), 29-38.

Li, H., Xu, L. C., \& Zou, H. F. (2000). Corruption, income distribution, and growth. Economics and Politics, 12, 155-182.

Lora, E. A., \& Chaparro, J. C. (2008). The conflictive relationship between satisfaction and income. In IDB Working Paper No. 542. Available at SSRN 1313875: https://papers.ssrn.com/sol3/papers.cfm?abstr act_id=1820930.

Morgan, R., \& Wang, F. (forthcoming). Growth and subjective well-being in China - Chapter 24. In E. Douarin \& O. Havrylyshyn (Eds.), The Palgrave Handbook of Comparative Economics. Basingstoke: Palgrave Macmillan.

Nikolova, M., \& Graham, C. (2014). In transit: The well-being of migrants from transition and posttransition countries. IZA discussion paper 8520 .

Nikolova, E., \& Sanfey, P. (2016). How much should we trust life satisfaction data? Evidence from the Life in Transition Survey. Journal of Comparative Economics, 44(3), 720-731.

Pasta, D. P (2009). Learning when to be discrete: Continuous vs. categorical predictors. Paper 248ICON Clinical Research, San Francisco, CA.

Powdthavee, N. (2005). Unhappiness and crime: Evidence from South Africa. Economica, 72, 531-547.

Rabe-Hesketh, S., \& Skrondal, A. (2012). Multilevel and longitudinal modeling using Stata, 3rd edn. StataCorp LP.

Ravallion, M., \& Chen, S. (1997). What can new survey data tell us about recent changes in distribution and poverty? World Bank Economic Review, 11(2), 357-382.

Rodríguez-Pose, A., \& Maslauskaite, K. (2012). Can policy make us happier? Individual characteristics, socio-economic factors and life satisfaction in Central and Eastern Europe. Cambridge Journal of Regions Economy and Society, 5(1), 77-96.

Roex, K., \& Rozer, J. J. (2018). The social norm to work and the well-being of the short- and long-term unemployed. Social Indicators Research, 139(3), 1037-1064.

Roland, G. (2014). Transition in historical perspective. In S. Djankov \& A. Aslund (Eds.), The great rebirth. Lessons from the victory of capitalism over communism. Washington: Peterson Institute for International Economics.

Rose-Ackerman, S. (1997). Corruption and good governance. UNDP discussion paper series no. 3. New York: United Nations Development Program.

Rotondi, V., \& Stanca, L. (2015). The effect of particularism on corruption: Theory and empirical evidence. Journal of Economic Psychology, 51, 219-235.

Sanfey, P., \& Namazie, C. (2001). Happiness and transition: The case of Kyrgyzstan. Review of Development Economics, 5(3), 392-405.

Sanfey, P., \& Teksoz, U. (2007). Does transition make you happy? Economics of Transition, 15(4), 707-731.

Saris, W. E. (2001). What Influences Subjective Well-being in Russia? Journal of Happiness Studies, 2(2), $137-146$.

Selezneva, E. (2011). Surveying transitional experience and subjective well-being: Income, work, family. Economic Systems, 35(2), 139-157.

Seligson, M. A. (2006). The measurement and impact of corruption victimization: Survey evidence from Latin America. World Development, 34(2), 381-404.

Senik, C. (2014). The French unhappiness puzzle: The cultural dimension of happiness. Journal of Economic Behavior and Organization, 106, 379-401.

Stevenson, B., \& Wolfers, J. (2008). Economic growth and subjective well-being: Reassessing the Easterlin paradox. National Bureau of Economic Research.

Sulemana, I., Iddrisu, A. M., \& Kyoore, J. E. (2017). A micro-level study of the relationship between experienced corruption and subjective wellbeing in Africa. The Journal of Development Studies, 53(1), 138-155. 
Tay, L., Herian, M., \& Diener, E. (2014). Detrimental effects of corruption and subjective well-being. Social Psychological and Personality Science, 5(7), 751-759.

Taylor, S., \& Lobel, M. (1989). Social comparison activity under threat: Downward evaluation and upward contacts. Psychological Review, 96(4), 569-575.

Veenhoven, R. (2001). Are the Russians as unhappy as they say they are? Journal of Happiness Studies, 2(2), 111-136.

Welsch, H. (2008). The welfare costs of corruption. Journal of Applied Economics, 40(14), 1839-1849.

Williams, C., \& Onoshchenko, O. (2015). Evaluating the validity of contrasting theoretical perspectives towards the informal economy in Ukraine. In J. Morris \& A. Polese (Eds.), Informal economies in post-socialist spaces: Practices, institutions and networks. London: Palgrave Macmillan.

Wu, Y., \& Zhu, J. (2016). When are people unhappy? Corruption experience, environment, and life satisfaction in Mainland China. Journal of Happiness Studies, 17(3), 1125-1147.

Publisher's Note Springer Nature remains neutral with regard to jurisdictional claims in published maps and institutional affiliations. 